\title{
LITIGATING ON ONE'S DOORSTEP: AcCess to Justice And THe Question of Venue
}

\begin{abstract}
ANNA J. LUND*
Venue rules govern the location where legal proceedings are commenced and where applications and trials are heard. These rules can hamper litigants from participating in legal proceedings, such as when they require a litigant to travel a significant distance to take part in a hearing or trial. The expense and time required for such travel is prohibitive for some litigants.
\end{abstract}

In this article, the author considers the extent to which the venue rules in Alberta hamper defendants from participating in three types of proceedings: mortgage default proceedings, residential eviction proceedings, and enforcement proceedings against a judgment debtor's real property. The venue rules applicable to these proceedings raise serious access to justice issues because the defendants are commonly self-represented and are at risk of losing their homes.

This article argues that Alberta venue rules are somewhat responsive to the plight of defendants, but they could be revised to ensure that self-represented litigants, especially those of limited means, can participate in legal proceedings regarding their homes. Changes to the substance of the rules must be matched with changes to the practices by which these rules are invoked, because these practices create additional hurdles for the defendants.

\section{TABLE OF CONTENTS}

I. Litigating on SOMEOne Else's DoORSteP . . . . . . . . . . . . . . . . 1040

II. LOSING A House THROUGH LEGAL PROCEEDINGS:

Mortgage Defaults, Evictions, And Writ Enforcement . . . . . . 1043

A. The Nature of the Disputes and Remedies Available . . . . 1044

B. Alberta's COURTS AND TRIBUNALS . . . . . . . . . . . . . . . . 1045

III. THE HISTORY AND DEVELOPMENT

OF Alberta's Venue Rules . . . . . . . . . . . . . . . . . . . . . . 1047

A. A Short History of English Venue Rules . . . . . . . . . . . 1047

B. THE HistoricAl DEVELOPMENT

OF AlBERTA's VENUE RULES . . . . . . . . . . . . . . . . . . . . . . 1049

IV. Alberta's Current Venue Rules . . . . . . . . . . . . . . . . . 1053

A. COMMENCING AN ACTION IN THE

COURT OF QUEEN's BENCH . . . . . . . . . . . . . . . . . 1054

B. Changing the Venue in the

COURT OF QUEEN's BENCH . . . . . . . . . . . . . . . . . . . . 1056

C. Venue Rules: The Provincial Court . . . . . . . . . . . . . . . . 1061

D. Venue Rules: Residential TenANCY TRIBUnAL . . . . . . . . . . 1061

E. REMOTE APPEARANCES . . . . . . . . . . . . . . . . . . . . . . . . 1062

V. PotentiAL REFORMS . . . . . . . . . . . . . . . . . . . . . . . . . . . . . . . . . 1064

A. REFORMING THE CONTENT OF THE RULES . . . . . . . . . . . . . 1066

B. REForming RELATEd PRACTICES ... . . . . . . . . . . . . 1071

Assistant Professor, Faculty of Law, University of Alberta. The author wishes to thank Barbara Billingsley and Scott Matheson for their comments on earlier drafts of this article, Jesse Chisholm for her careful editing of the footnotes, and the anonymous reviewers for providing exceptionally constructive and thought-provoking feedback during the peer review process. 


\section{Litigating on Someone Else's DOORSTEP ${ }^{1}$}

In the early 1980s, Alberta went through a serious recession at the same time that interest rates soared. Many Albertans struggled to pay their bills and the number of lenders taking default proceedings on home mortgages spiked. In one such case the lender started legal proceedings against two homeowners with the last name Reddick. ${ }^{2}$ A little can be gleaned about the Reddicks from the brief written judgment in their matter. They had borrowed money from Alberta Home Mortgage Corporation, a statutory entity established by the Government of Alberta to provide housing loans to low- and moderate-income individuals. ${ }^{3}$ The Reddicks used their loan to purchase a house in Calgary. When Alberta Home Mortgage Corporation started mortgage default proceedings against them, the Reddicks hired a lawyer to represent their interests.

Alberta Home Mortgage Corporation started its legal proceedings in Edmonton, a city 300 kilometres away from where the Reddicks lived. In the 1980s, the procedural rules in Alberta only governed the place of trial. ${ }^{4}$ A plaintiff could start a lawsuit in any judicial centre as long as their choice was not "capricious" — meaning "guided by whim or fancy rather than by judgement or settled purpose." The Court would hear any pre-trial applications in the location where the lawsuit was started. ${ }^{7}$ In mortgage default proceedings, like the one started against the Reddicks, the rules required that the trial take place in the judicial centre located nearest to the land, that is, Calgary. ${ }^{8}$ However, both then and now, courts could resolve most mortgage default proceedings on the basis of pre-trial applications; ${ }^{9}$ trials were and are rare. In the Reddicks' case, the lender would likely be able to complete the entire mortgage default proceeding in Edmonton, without ever appearing in a Calgary courtroom.

The Reddicks' lawyer applied to have the pre-trial matters moved to Calgary, but the Court dismissed this application. At the time, defendants could only get a matter moved if they could show that a preponderance of convenience favoured the transfer. ${ }^{10}$ The Court noted that at pre-trial applications, evidence would be provided in writing by way of sworn affidavits and not orally by witnesses. The Court reasoned that it was equally inconvenient for the lender to swear affidavits in Edmonton and have them mailed to Calgary as it was for

The title is taken from Bank of British Columbia v Barber (1984), 35 Alta LR (2d) 219 (QB) at 222 [Barber], where the Court noted: "It is procedurally more convenient to conduct litigation on one's doorstep, so to speak, than it is to conduct it at a distance of a few hundred miles."

Alberta Home Mortgage Corporation v Reddick (1982), 20 Alta LR (2d) 395 (QB) [Reddick].

Alberta Home Mortgage Corporation Act, RSA 1980, c A-28, s 3.

Alberta, Rules of Court, AR 390/1968, r 237 [Rules of Court (1968)].

Reddick, supra note 2 at 397, citing Wade Investments Ltd v Hat Travel Ltd (1979), 21 AR 454 (QB)

at para 3 [Wade Investments], citing Church v Barnett (1871), 6 LR CP 116 (Ct Com Pl) at 119. Oxford English Dictionary, 2nd ed, sub verbo "capricious."

Francis CR Price \& Marguerite J Trussler, Mortgage Actions in Alberta: The Law and Practice in Actions Upon Mortgages and Collateral Security and Agreements for Sale of Land (Calgary: Carswell Legal Publications, 1985) at 32.

$8 \quad$ Rules of Court (1968), supra note 4, r 237(c).

$9 \quad$ Price \& Trussler, supra note 7 at 33. For an overview of mortgage default proceedings, see Centre for Public Legal Education Alberta, "Foreclosure in Alberta" (Edmonton: Centre for Public Legal Education Alberta, 2015), online: <https://p.b5z.net/i/u/10086419/f/ForeclosureGeneral.pdf $>$ [CPLE, "Foreclosure"]. 
the Reddicks to swear affidavits in Calgary and mail them to Edmonton. ${ }^{11}$ If the Court heard the matter in Edmonton, the Reddicks would need to pay for their lawyer to travel there or retain a new lawyer in Edmonton. Hearing the matter in Calgary would cause a similar inconvenience to the lender. The Court surmised that hearing the matter in Edmonton was as inconvenient for the Reddicks as hearing the matter in Calgary would be for the lender, and so it could not be said that a preponderance of convenience favoured a transfer to Calgary. ${ }^{12}$ If the Reddicks wanted to contest the mortgage proceedings against their Calgary home, they or their lawyer would need to appear in an Edmonton courtroom.

Access to justice can mean many different things. ${ }^{13}$ One component of access to justice includes a litigant's ability to be present in the court or tribunal in which their matter will be decided; physical distance from a court location can limit one's ability to access justice. ${ }^{14} \mathrm{~A}$ litigant forced to respond to proceedings in a distant courthouse will incur increased out-ofpocket travel costs (such as mileage) and temporal costs (such as time spent travelling to and from the courthouse).$^{15}$ In some cases, these costs will preclude a litigant from attending a proceeding. ${ }^{16}$ Litigants of limited means may face particular struggles when faced with the cost of travelling to a distant courthouse. ${ }^{17}$ An adverse party may succeed simply because the litigant is not present to voice their position.

Having the ability to participate in proceedings is especially important when legal proceedings relate to an individual's home. Housing is a basic necessity and the loss of

Price \& Trussler, supra note 7 at 31 (note that it was more difficult for a defendant to satisfy the "preponderance of convenience test" when a transfer application related to pre-trial matters where evidence would be provided by way of affidavit. A number of cases decided in the 1980s evidence this principle). See e.g. Blue River Heavy Hauling Ltd v Cal-Van Auctioneering Ltd (1987), 87 AR 67 (QB) at para 17; Barber, supra note 1 at 223.

12 Reddick, supra note 2 at 398.

13 See Roderick A Macdonald, “Access to Justice and Law Reform” (1990) 10 Windsor YB Access Just 287.

14 Wayne Renke, “A Single Trial Court for Alberta: Consultation Paper" (Edmonton: Alberta Justice, 2003) at para 23, online: <www.cfcj-fcjc.org/sites/default/files/docs/hosted/18550-single_trial_court consult.pdf.>; Consultation Memorandum from Alberta Law Reform Institute, "Alberta Rüles of Court Project: Self-Represented Litigants” (Edmonton: Alberta Law Reform Institute, 2005) at para 29, online: $<$ https://www.alri.ualberta.ca/docs/cm01218.pdf $>$ [Alberta Law Reform Institute, "Self-Represented Litigants"].

15 Noel Semple, "The Cost of Seeking Civil Justice in Canada" (2015) 93:3 Can Bar Rev 639 at 644; Shannon Salter, "Online Dispute Resolution and Justice System Integration: British Columbia's Civil Resolution Tribunal" (2017) 34:1 Windsor YB Access Just 112 at 119. Trevor Farrow et al. found that "transportation costs" were the second most frequently reported expense incurred by Canadians when they attempted to resolve their legal problems: see "Everyday Legal Problems and the Cost of Justice in Canada: Overview Report" (Toronto: Canadian Forum on Civil Justice, 2016) at 14-15, online: $<$ www.cfcj-fcjc.org/sites/default/files/Everyday $\% 20$ Legal $\% 20$ Problems $\% 20$ and $\% 20$ the $\% 20$ Cost $\% 20$ of $\% 20$ Justice $\% 20$ in $\% 20$ Canada $\% 20-\% 20$ Overview\%20Report.pdf $>$.

16 In his ethnography of evictions in Milwaukee, Matthew Desmond describes how one tenant chose not to attend court because it would require her to miss time at work: Evicted: Poverty and Profit in the American City (New York: Broadway Books, 2016) at 99. In Alberta, Mary Stratton found that geography and lack of access to public transportation both impeded individuals from accessing legal services: "Alberta Legal Services Mapping Project: An Overview of Findings from the Eleven Judicial Districts" (Canadian Forum on Civil Justice, 2011) at 42, 47-48, online: <cfcj-fcjc.org/sites/default/ files/docs/2011/mapping-final-en.pdf $>$. See also Patricia Hughes, "Advancing Access to Justice Through Generic Solutions: The Risk of Perpetuating Exclusion” (2013) 31:1 Windsor YB Access Just 1 at $6,15-16$.

17 In a similar vein, when studying access to services provided by lawyers, Jamie Baxter and Albert Yoon found that "lower- and middle-income clients may disproportionately experience geographic barriers to access": "No Lawyer for a Hundred Miles? Mapping the New Geography of Access of Justice in Canada" (2014) 52:1 Osgoode Hall LJ 9 at 49. 
housing negatively impacts an individual's physical and mental well-being. ${ }^{18}$ The Supreme Court of Canada has emphasized that in matters of civil procedure, proportionality is a guiding principle. ${ }^{19}$ Proportionality means that the procedure used to resolve a dispute is attuned to the complexity of the dispute, but it also means that the procedure is attuned to the nature of the dispute, including the significance of the consequences for the litigants. ${ }^{20}$ Thus, before subjecting an individual to serious jeopardy, such as the loss of their home, the rules of civil procedure should ensure that an individual has a meaningful opportunity to advance any defences available to them.

This article considers three different types of legal proceedings where an individual stands to lose their home: (1) mortgage default proceedings, (2) residential eviction proceedings, and (3) judgment enforcement proceedings. A key feature common to each of these three proceedings is that they are often commenced against individuals of limited means, who lack the ability to afford legal representation. ${ }^{21}$ If they participate in the proceedings at all, they participate as self-represented litigants. ${ }^{22}$ And if they are sued in a jurisdiction other than the one where they live, these defendants may not be able to participate. ${ }^{23}$ The rules governing the venue for legal proceedings can determine whether or not a person has a "meaningful opportunity to be heard." 24

Alberta's venue rules have changed since the Court of Queen's Bench ruled on the Reddicks' transfer application. The rules now restrict where a plaintiff can start an action, and it has become easier for defendants to have matters moved, especially in mortgage default proceedings. Additionally, courts have recognized that access to justice can be an important consideration when deciding where in the province a lawsuit should be heard. When a litigant is unable to attend a hearing in person, the court can allow the litigant to participate in the hearing using electronic means, such as a teleconference or videoconference. These shifts help ensure that Albertans, especially those of limited means, are not excluded from legal proceedings as a result of their physical distance from a courthouse. But despite these desirable developments, some gaps remain in the law and the

18 For example, article 11 of the International Covenant on Economic, Social and Cultural Rights, 16 December 1966, 993 UNTS 3 (entered into force 3 January 1976) recognizes housing as a fundamental requirement for an adequate standard of living. On the negative impacts caused by the loss of housing, see Hughes, supra note 16 at 8-9; Desmond, supra note 16 at 296.

Hryniak $v$ Mauldin, 2014 SCC 7 at paras 23-33.

Szeto $v$ Dwyer, 2010 NLCA 36 at paras 52-54, cited in Hryniak, ibid at para 31.

State-funded legal representation (such as legal aid) is not available for the three types of matters discussed in this article. It is limited to individuals earning under a threshold amount (for example, $\$ 20,021 /$ year for a one-person household) and who have a legal problem that falls into one of the covered categories including: (1) charges for serious criminal offences, (2) charges for youth criminal offences, (3) some family matters, (4) immigration and refugee claims, and (5) adult guardianship and trusteeship matters. See Legal Aid Alberta, "Rules 2019" (Legal Aid Alberta, 2019), online: <www.legal aid.ab.ca/information-resources/Documents/Rules\%20and\%20Policies/LAA\%20Rules\%20April\%201 \%202019.pdf>; Legal Aid Alberta, “Administrative Policy 01 - Service Eligibility" (Legal Aid Alberta, 2015), online: <www.legalaid.ab.ca/information-resources/Documents/Rules\%20and\%20Policies/ Administrative \%20Policy\%2001\%20-\%20Service\%20Eligibility.pdf>.

22 In Canadian Imperial Bank of Commerce v Nemeth, 2013 ABQB 290 at para 10 [Nemeth], Master Schlosser commented, "It is not unusual for unrepresented Defendants to appear in foreclosure actions." In National Holdings Ltd v Blair, 2009 ABQB 351 at para 11 [National Holdings], Master Hanebury noted "defendants in foreclosure actions are frequently in difficult circumstances. They often cannot afford the assistance of counsel."

23 Lim v Young, 2004 ABQB 489 at para 9 [Lim], cited with approval in National Holdings Ltd, ibid at para 4.

24 Harriet B Rosen, "Nearer Thy Court to Thee: A Proposal for a More Convenient Forum for Defendants in Consumer Cases" (1976) 8:3 Conn L Rev 530 at 549. 
procedural complexity of challenging a plaintiff's venue choice or accessing electronic hearings puts these solutions out of reach for many self-represented litigants.

This article considers the extent to which the venue rules in Alberta facilitate an individual defendant's participation in mortgage default proceedings, residential eviction proceedings, and judgment enforcement proceedings. Part II provides a primer on each of the three types of legal proceedings being discussed, including the nature of the dispute, the remedies being sought, and the courts or tribunals that are tasked with deciding these matters. Part III traces the development of Alberta's venue rules from their early English predecessors to the present day. Part IV describes the current venue rules, synthesizes the case law interpreting them, and considers how they apply to each of the three proceedings. This Part identifies gaps in the current approach and considers the extent to which these gaps are addressed through technological innovations that allow for remote appearances. Part V concludes by recommending changes to the content of the rules and related practices that would better enable self-represented litigants to participate in legal proceedings and protect against them losing their homes when they have a meritorious defence.

\section{Losing a House through Legal Proceedings: Mortgage Defaults, EVICTIONS, AND Writ EnForCEMENT}

Mortgage default proceedings, residential eviction proceedings, and judgment enforcement proceedings are three ways by which someone can lose their home through legal proceedings in Alberta. These proceedings impact a large number of Albertans. Between April 2016 and March 2017, the Government of Alberta reports that there were 5,746 foreclosures in the province. ${ }^{25}$ In that same period, bailiffs were hired to evict 1,354 tenants from their rented premises, and judgment enforcement proceedings were commenced against 425 properties. ${ }^{26}$ The evictions statistic does not capture tenants who leave earlier in the eviction process. ${ }^{27}$ In 2015-2016, the specialized residential tenancy tribunal scheduled 9,258 hearings. ${ }^{28}$ Though not all of these hearings would involve landlords seeking to evict tenants, the number suggests that thousands of Albertans are evicted every year.

This section provides a primer on the nature of the dispute and the types of remedies available for each of the three types of proceedings where an individual may lose their home. It then provides an overview of the different courts and tribunals in Alberta that are tasked with resolving these types of disputes.

Emily Mertz, "Foreclosures in Alberta Up About 25\% Annually for Past 2 Years," Global News (16 May 2017), online: <https:/globalnews.ca/news/3455634/foreclosures-in-alberta-up-about-25-annuallyfor-past-2-years/>.

26 Office of the Sheriff - Civil Enforcement, "Civil Enforcement Agencies' Activity: April 2016 - March 2017" (Justice and Solicitor General, 2017), online: <https://open.alberta.ca/dataset/0cef2cfd-37f7-4b008b56-78b9d5 ce1ba5/resource/d43c46a1-8d7a-4b57-a487-d9ed0c148f3d/download/civil-enforcementagencies-activity-2016-2017-final.pdf>.

27 Anna Lund, Book Review of Evicted: Poverty and Profit in the American City by Matthew Desmond (2016) 54:1 Alta L Rev 233 at 239.

28 Service Alberta, “Annual Report 2015-2016" (Service Alberta, 2016) at 9, online: <www.service alberta.gov.ab.ca/pdf/annual/SA Annual Report 15-16.pdf>. 


\section{A. The Nature OF The Disputes ANd Remedies AVAilable}

A secured lender starts a mortgage default proceeding when a homeowner has breached the terms of a loan agreement called a mortgage. Most people cannot afford to purchase a home outright, so instead they borrow money. The party lending the money - often a financial institution, but sometimes a private individual - is granted a form of proprietary right in the purchased land. ${ }^{29}$ If the homeowner defaults under the loan agreement, the lender can enforce their proprietary right in the home by starting mortgage default proceedings. ${ }^{30}$ The lender will usually attempt to find a third-party buyer for the home, and the lender's loan will be repaid from the sale proceeds. However, if no one is willing to pay above a threshold amount, the lender can take title to the property in its own name. This remedy, where the lender becomes the owner, is called a foreclosure. ${ }^{31}$ Colloquially, mortgage default proceedings are called foreclosures.

A landlord starts eviction proceedings against a residential tenant when the tenant has breached a term of a tenancy agreement. In this scenario, the landlord owns a piece of property and has allowed the tenant to reside at the property as long as the tenant complies with the terms of the tenancy agreement. These terms may be either explicitly agreed to by the landlord and the tenant or imposed through legislation. ${ }^{32}$ A fundamental term of any tenancy agreement is the right of the landlord to receive periodic rent payments, and many eviction applications are brought by landlords against tenants who have fallen behind on rent. ${ }^{33}$ However, there are other grounds upon which a landlord may seek to terminate a tenancy, including if a tenant damages the rental property or is violent towards the landlord or another tenant. ${ }^{34}$ If a landlord succeeds on an eviction application, they will receive an order requiring the tenant to vacate the premises. The order may contemplate additional relief, such as payment by the tenant of overdue rent.

The Residential Tenancies Act governs most residential tenancies in Alberta; however, some relationships are governed by special legislation. ${ }^{35}$ For example, an individual living in a mobile home park commonly owns the mobile home in which they live but rents the land on which it sits. The Mobile Home Sites Tenancies Act governs this type of rental agreement. $^{36}$

The third type of proceeding discussed in this article is the sale of a house to satisfy a writ. One party (alternatively called a writ creditor, a judgment creditor, or an enforcement

Law of Property Act, RSA 2000, c L-7, ss 37-50 [LPA]; Alberta, Rules of Court, AR 124/2010, rr 3.41, 3.77, 6.5, 9.30-9.36, 11.23-11.24 [Rules of Court (2010)]. See also CPLE, "Foreclosure," supra note 9.

LPA, ibid, s 48

See e.g. Residential Tenancies Act, SA 2004, c R-17.1 [RTA].

A 1994 study of landlord-tenant proceedings in Ontario found that 95 percent of landlord-tenant claims were initiated by the landlord for arrears of rent while only 6 percent of these cases were disputed by tenants: see Julie Macfarlane, "The Landlord/Tenant Dispute Resolution Project: Final Report \& Recommendations" (1994), cited in Ontario, Ministry of the Attorney General, Ontario Civil Justice Review: Supplemental and Final Report, (Toronto: Queen's Printer for Ontario, 1995) at ch 6.3, online: $<$ https://www.attorneygeneral.jus.gov.on.ca/english/about/pubs/cjr/suppreport/ch63a.php\#Note\%204>. RTA, supra note 32, s 30; Mobile Home Sites Tenancies Act, RSA 2000, c M-20, ss 32-33 contains comparable provisions.

RTA, ibid, s 2(2).

Supra note 34. 
creditor) uses writ proceedings to compel another party to pay a judgment. A judgment is a court order that directs one party to pay money to another. Judgments are granted in a multitude of situations. For example, one party may sue another for breaching a contract, for committing a tort, for being unjustly enriched at the plaintiff's expense, or - as described above - for unpaid rent. If successful, the court may order the defendant to compensate or reimburse the plaintiff. On the other hand, if the plaintiff is unsuccessful, the court may order the plaintiff to compensate the defendant for its litigation costs. All of these orders are judgments. Once a party has been granted a judgment, the judgment debtor may willingly pay it. Conversely, the judgment debtor may be unable or unwilling to pay. The judgment creditor can then start writ proceedings to compel payment. ${ }^{37}$ These proceedings can take many forms, including seizing and selling personal property, garnishing payments owed to the debtor, or selling the debtor's real properly, including the debtor's home. ${ }^{38}$

\section{B. Alberta's Courts And Tribunals}

The venue rules applicable to a legal proceeding vary depending on the plaintiff's choice of court or tribunal because each court and tribunal has its own procedural rules. In Alberta, litigants may start claims in either the Provincial Court or the Court of Queen's Bench. The Court of Queen's Bench has the inherent jurisdiction to hear any matter, unless its jurisdiction has been circumscribed by statute. ${ }^{39}$ The Provincial Court is a statutory court and only has jurisdiction to hear matters that have been delegated to it through legislation. The civil division of the Provincial Court can hear most civil claims where the amount claimed falls below a prescribed limit, currently $\$ 50,000 .{ }^{40}$ There are some additional limits on the Provincial Court's jurisdiction, including that it cannot adjudicate a claim "in which the title to land is brought into question."

In mortgage proceedings, the title of land is brought into question, and therefore they must be commenced in the Court of Queen's Bench and are governed by the venue rules set out in the Rules of Court. ${ }^{42}$

Landlords applying to evict a tenant from residential premises have the option of starting their claim in the Provincial Court or the Court of Queen's Bench. ${ }^{43}$ Additionally, for those premises governed by the Residential Tenancies Act, landlords can bring eviction applications against tenants in a specialized tribunal called the Residential Tenancy Dispute Resolution Service (the Residential Tenancy Tribunal). The provincial government

RA 2000, c C-15 [CEA]

In Saskatchewan, enforcement creditors are not allowed to sell a debtor's "active residence": Enforcement of Money Judgments Act, SS 2010, c E-9.22, ss 93(1)-(2); Tamara M Buckwold, "The Reform of Judgment Enforcement Law in Canada: An Overview and Comparison of Models for Reform" (2017) 80:1 Sask L Rev 71 at 119. The creditors are limited to registering their judgment against the property and then waiting to be paid when the debtor stops using the property as an active residence.

39 Judicature Act, RSA 2000, c J-2, ss 2-9.

40 Provincial Court Act, RSA 2000, c P-31, s 23(1)(a) [PCA]; Provincial Court Civil Procedure Regulation, Alta Reg 176/2018, s 2 (previously Provincial Court Civil Division Regulation, Alta Reg $329 / 1989$, s 1.1 .

PCA, ibid, s 24(a).

Rules of Court (2010), supra note 30.

RTA, supra note 32 , ss 48, 54(1); PCA, supra note 40, s 23(1). A money judgment granted by the Residential Tenancy Tribunal can be filed at the Court of Queen's Bench and enforced as an order of that Court: Residential Tenancy Dispute Resolution Service Regulation, Alta Reg 98/2006, s 22(1). 
established the Residential Tenancy Tribunal to provide landlords and tenants with a less formal process for having their disputes resolved. Like the Provincial Court, the Residential Tenancy Tribunal only has jurisdiction to hear matters that have been delegated to it by its enabling legislation. Landlords applying to evict a mobile home owner from a leased site can apply to either the Provincial Court or the Court of Queen's Bench - they do not have recourse to the Residential Tenancy Tribunal. ${ }^{44}$

The Court of Queen's Bench is tasked with supervising writ enforcement proceedings; however, the proceedings are based on an underlying judgment, which may emanate from the Provincial Court, the Court of Queen's Bench, or elsewhere. ${ }^{45}$ A plaintiff who sues in the Provincial Court and gets judgment must register that judgment with the Court of Queen's Bench before taking enforcement proceedings. ${ }^{46}$ Consequently, a matter may be started in the Provincial Court, using its venue rules, and then continued in the Court of Queen's Bench once the claim has crystallized into a judgment. The Rules of Court would govern any application for a change of venue once a judgment creditor commences writ enforcement proceedings.

The rules regarding where different proceedings can be commenced are summarized below in Table 1.

TABLE 1: COURTS AND TRIBUNALS

Tasked With Different Proceedings Related to Housing

\begin{tabular}{|l|c|c|c|}
\hline & $\begin{array}{c}\text { Court of Queen's } \\
\text { Bench }\end{array}$ & Provincial Court & $\begin{array}{c}\text { Residential } \\
\text { Tenancy Tribunal }\end{array}$ \\
\hline $\begin{array}{l}\text { Mortgage Default } \\
\text { Proceedings }\end{array}$ & $\cdot$ & & \\
\hline $\begin{array}{l}\text { Eviction Proceedings } \\
\text { Residential Tenancies Act) }\end{array}$ & $\cdot$ & & \\
\hline $\begin{array}{l}\text { Eviction Proceedings } \\
\text { (Mobile Homes Sites } \\
\text { Tenancies Act) }\end{array}$ & $\cdot$ & & \\
\hline Writ Proceedings & & & \\
& & & \\
\hline
\end{tabular}




\section{THE HISTORY AND DEVELOPMENT of Alberta's Venue RULES}

Venue rules must answer two main questions: where should an action be adjudicated, and when will an action be transferred from one venue to another? The history of English and Albertan venue rules shows that the answers to these questions have changed over time as legislators have attempted to balance the interests of plaintiffs, defendants, and concerns regarding trial and enforcement efficacy. Plaintiffs wish to have a wide scope of discretion, to sue in whatever venue is most convenient to them. Yet, if a plaintiff's discretion is not circumscribed, they may choose to litigate a matter in a venue that is inconvenient for a defendant or impractical, given how the claim will be adjudicated or enforced. For example, when many of the witnesses are located near to one venue, it may be impractical to adjudicate the claim elsewhere. Venue rules can constrain plaintiffs' discretion by requiring that claims be adjudicated at a location to which the claim is connected. Possible connecting factors include the location where the cause of action arose or the place where the litigants reside or carry on business. A plaintiff's discretion can also be checked by venue rules that allow the defendant or the court to transfer a claim from an inconvenient or impractical location to a more appropriate one.

Understanding the historical precursors to Alberta's venue rules is important when assessing their current content. This section begins with a brief overview of the English precursors to Alberta's venue rules, followed by a more detailed description of how Alberta's venue rules have evolved since the province's creation in 1905. The English venue rules emphasized the location in which a cause of action arose as an important connecting factor and prescribed special venue rules for litigation involving land. These two elements are still features of Alberta's venue rules, and it is worth considering whether the reasons for initially adopting these venue rules still carry weight or if the context of litigation has changed sufficiently to warrant a change to the rules. The Alberta history reveals ongoing experimentation with different formulations of the venue rules. The current iterations are not sacrosanct, and previous iterations offer useful precedents for those who wish to engage in further experimentation.

\section{A. A Short History of English Venue Rules}

The venue rules governing actions in Alberta evolved from English common law rules, which developed hundreds of years ago in a legal system that looked very different from the contemporary Canadian one. Early in the history of the common law, juries played an important role in resolving legal disputes; however, they differed in an important respect from contemporary juries - they were not disinterested arbiters but witnesses. ${ }^{47}$ The jurors were expected to bring "their own knowledge of the matter in dispute" that would help them to resolve the matter. ${ }^{48}$ To ensure they had sufficient knowledge, it was important that the

\footnotetext{
47 AKR Kiralfy, Potter's Historical Introduction to English Law and Its Institutions, 4th ed (London: Sweet \& Maxwell, 1962) at 342.

48 R Ross Perry, Common-Law Pleading: Its History and Principles (Boston: Little, Brown, and Company,
} $1897)$ at 323 . 
jurors be drawn from the locality where the dispute arose. ${ }^{49}$ Litigants had to indicate in their pleadings where a matter arose so that the sheriff knew the locality from which he should summon the jurors. ${ }^{50}$ In 1383, in response to litigants starting claims in the wrong venue, legislators passed a statute requiring that claims be brought in the venue where they arose. ${ }^{51}$ In 1402, legislators went a step further and required attorneys to take an oath that "they make no Suit in a foreign County." ${ }^{, 52}$ By 1630 , the rules of court dictated penal consequences for attorneys who breached this oath. ${ }^{53}$

The role of the jurors eventually evolved from that of witnesses to that of neutral arbiters, and it was no longer expected they would bring specific knowledge of the dispute to the trial. ${ }^{54}$ Consequently, it was no longer necessary for the sheriff to summon jurors from the locality where the dispute arose..$^{55}$ At the same time that less emphasis was being placed on venue, a different problem had arisen. Court judgments were being challenged on the basis that they had been tried in the wrong venue. ${ }^{56}$ Legislators accepted that unsuccessful litigants should not be able to challenge judgments on the basis of this technical objection and, in 1664 , passed a statute preventing such challenges ${ }^{57}$ Following the passage of this statute, it became more common for litigants to sue in a venue other than the one where the dispute arose - unless the subject matter of the dispute was real property. ${ }^{58}$ Courts required lawsuits over real property to be brought in the venue where the property was located. ${ }^{59}$ The special treatment of real property was justified by several factors, including that the court's jurisdiction may not extend to property located in a foreign locale, that the pleadings must accurately state the location of the land and this statement of location used to be determinative of venue, that it would be easier for a successful plaintiff to enforce a court order against the property, and that the decision-maker would be able to take a view of the property, if necessary. ${ }^{60}$

As plaintiffs acquired more choice regarding where to start an action, the English rules also evolved to provide defendants with the ability to challenge the plaintiff's choice of venue. Beginning during the reign of James I (1603-1625), defendants could apply to have a matter transferred to a different venue if they provided affidavit evidence that the action arose in the venue to which the transfer was sought. ${ }^{61}$ By 1871, in Church v. Barnett, two of the four Justices of the Court of Common Pleas stated that the plaintiff's choice of venue was

\footnotetext{
49 Thomas Atkins Street, The Foundations of Legal Liability: A Presentation of the Theory and Development of the Common Law, vol 3 (Northport, NY: Edward Thompson Company, 1906) at 90; Benjamin J Shipman \& Henry Winthrop Ballantine, Handbook of Common-Law Pleading, 3rd ed (St Paul: West Publishing, 1923) at 451; John Twohig \& Jennifer Pawson, "Civil Venue in Ontario" (1997) 19:2 Adv Q 129 at 133-34.

Perry, supra note 48 at 324-26; Street, ibid at 90-91.

(UK), 6 Rich II, c 2 (1383); Street, ibid at 92.

(UK), 4 Hen IV, c 18 (1402); Street, ibid at 93.

Street, ibid.

Twohig \& Pawson, supra note 49 at 133-34.

Perry, supra note 48 at 327.

J Chitty, A Treatise on the Parties to Actions, the Forms of Actions, and on Pleadings, 3rd ed (London: S Brooke, 1817) at 282-84.

(UK), 16-17 Char II, c 8 (1664-1665); Perry, supra note 48 at 327-28.

Perry, ibid at 328; Shipman \& Ballantine, supra note 49 at 452-55; Chitty, supra note 56 at 267.

Perry, ibid at 329; Street, supra note 49 at 93-94.

Twohig \& Pawson, supra note 49 at 142; Shipman \& Ballantine, supra note 49 at 452-55; Chitty, supra note 56 at 267,283 .

Perry, supra note 48 at 330; Street, supra note 49 at 93.
} 
entitled to deference, unless the defendant could establish that a preponderance of convenience favoured having the matter tried in a different venue. ${ }^{62}$

\section{B. The Historical DEVELOPMENT of Alberta's Venue Rules}

This section describes the history of Alberta's venue rules and is organized by level of decision-maker. It starts by discussing the venue rules in the District Court and the Supreme Court - these were both precursors to the Alberta Court of Queen's Bench. Shortly after it became a province, in 1905, Alberta established a District Court that heard less significant civil and criminal matters and a Supreme Court that heard more significant ones. ${ }^{63}$ In 1919 , the Supreme Court was divided into a trial division and an appellate division. In 1978, the District Court and Supreme Court Trial Division were merged into the Court of Queen's Bench of Alberta and the Supreme Court Appellate Division became the Court of Appeal. ${ }^{64}$

\section{DISTRICT COURT}

The District Courts Act governed proceedings in the District Court. ${ }^{65}$ When it was enacted in 1907, it prescribed the location of trial for some categories of actions. For example, when a litigant sought recovery of land, or relief related to trespass or damage to land, the trial was to be held in the district where the land was located. ${ }^{66}$ In 1909 , courts were given the power to transfer proceedings to a different venue if satisfied that a "preponderance of convenience" favoured the other venue. ${ }^{67}$ This first venue rule, prescribing the place of trial for special categories of actions, remained in the legislation up until the District Court was merged with the Court of Queen's Bench in 1978. ${ }^{68}$

A second venue rule for District Court proceedings was initially set out in its rules of court. When Alberta first became a province, it continued to follow the rules of court that had been in force in the Northwest Territories. ${ }^{69}$ These rules contained provisions applicable to small debt actions, including a venue rule that allowed judges to set a matter down for trial in a place they considered expedient and a provision that empowered litigants to apply to have the place of trial changed before the matter was heard. ${ }^{70}$

Church v Barnett, supra note 5. The ratio of this case is open to multiple interpretations. Three of the judges indicated that they were loath to set aside a lower court's discretionary decision on the transfer application, and two went so far as to say they may have decided the matter differently at first instance: see Chief Justice Bovill and Justices Willes and Smith. Chief Justice Bovill cited deficiencies with the affidavit evidence as a basis for denying the appeal.

District Courts Act, SA 1907, c 4; The Supreme Court Act, SA 1907, c 3. The Provincial Archives of Alberta have an online resource tracing the history of courts in Alberta: "Law \& Original Order: Discovering Alberta's Court Records" (2014), online: <provincialarchives.alberta.ca/how-to/explorelearning-and-education/discovering-albertas-court-records/Default.aspx $>$. The Court of Appeal Act, SA 1978, c 50; The Court of Queen's Bench Act, SA 1978, c 51.

District Courts Act, supra note 63.

Ibid, s 32 .

An Act to Amend the Statute Law (Part 1), SA 1909, c 4, s 13(2).

The District Courts Act, RSA 1942, c 121, s 33, amended by The Surrogate Courts Act, SA 1967, c 79, s 27 (removed a rule specifying the place of trial for matters concerning wills), restated as The District Courts Act, RSA 1970, c 111, s 31.

69 The Judicature Ordinance, SNWT 1898, c 21 [Judicature Ordinance (1898)], adopted by The Supreme Court Act, supra note 63, s 36; District Courts Act, supra note 63, s 35. See also Institute of Law Research and Reform, "Report No 15: Validity of the Alberta Rules of Court" (Edmonton: University of Alberta, 1974), online: <https://www.alri.ualberta.ca/docs/fr015.pdf >. 
In 1914, Alberta promulgated its own rules of court, including Rules Relating to Small Debt Procedure in the District Courts. ${ }^{71}$ These rules specified that a trial of a small debt action should be held where the cause of action arose or where the defendant resided or carried on business. ${ }^{72}$ If the plaintiff named some other place as the place of trial, the Court could transfer the matter, award costs against the plaintiff, or do both. ${ }^{73}$ By 1923 , the rules applicable to small debt claims - including the rules governing the place of trial and the transfer of an action - had been consolidated into the Rules of Court, along with the rules governing Supreme Court proceedings. ${ }^{74}$ Additionally, these venue rules were made applicable to every action started in the District Courts, not only to small debt matters. ${ }^{75}$

In 1933, a version of the second venue rule was added to the District Courts Act. It prescribed that a lawsuit should be commenced and carried on in the judicial district where the defendant resided or carried on business. ${ }^{76}$ The plaintiff could commence proceedings in the judicial district where the cause of action arose, but only if the defendant was no longer located in Alberta. This new formulation of the rule gave the plaintiff less choice about venue by requiring the plaintiff to start its litigation near to a defendant's residence or place of business as long as the defendant remained in Alberta. In 1946, the venue rule was amended to reinvest the plaintiff with more scope for discretion - it could again commence and carry on an action where the defendant resided or carried on business or where the cause of action arose. ${ }^{77}$ The judge could allow for a matter to be heard in a different location if "special grounds" warranted exceptional treatment. ${ }^{78}$

\section{Supreme Court of Alberta: Trial Division}

The Judicature Act governed proceedings in the Trial Division of the Supreme Court of Alberta. ${ }^{79}$ Unlike the District Courts Act, it contained no venue rule. The Rules of Court enacted under the Judicature Act also initially lacked any venue rules. Proceedings were commenced where a plaintiff filed its commencing documents, and all subsequent proceedings were carried out in that location. ${ }^{80}$ A plaintiff could start an action in any venue, subject only to the Court's ability to transfer an action after it had been started. ${ }^{81}$ By 1944 ,

The Order in Council adopting these rules is referenced in Alberta Rules of Court, (1914) A Gaz X, 765. They took effect 1 September 1914. In An Act to amend the Statute Law, SA 1918, c 4, s 5, the Alberta legislature specified that the Alberta, Rules of Court, as amended 1 September 1923 [Rules of Court (1914)] replaced the Judicature Ordinance (1898). This was further confirmed in the The Judicature Act, SA 1919, c 3, s 59 [Judicature Act (1919)], which repealed the Judicature Ordinance (1898), ibid.

"Rules Relating to Small Debt Procedure in the District Courts" in The Consolidated Rules of the Supreme Court of Alberta (Calgary: Burroughs \& Company, 1914), r 16 [Consolidated Rules]. Ibid, $\mathrm{r} 18$.

Alberta, Rules of Court (1914), supra note 71, rr 801, 803.

Ibid, $\mathrm{r} 119 \mathrm{a}$. This rule was subsequently amended so that a plaintiff could start an action in the judicial district where the defendant resided at the time the action was commenced but required leave to start the action in the judicial district where the cause of action arose: see Rules of Court Amended: Rule of Court Repealed and Substituted, OC 1585-28, (1928) A Gaz XXIV, 721; Rules of Court Amended, OC 94-29, (1929) A Gaz XXV, 79.

The District Courts Act Amendment Act, SA 1933, c 15, s 2, as amended by The District Courts Act Amendment Act, 1936, SA 1936, c 20, s 6, restated as The District Courts Act, RSA 1942, c 121, s 28. An Act to amend the District Courts Act, SA 1946, c 37, s 1 [District Courts Act (1946)], restated as The District Courts Act, RSA 1955, c 87, s 30 [District Courts Act (1955)], restated as The District Courts Act, RSA 1970, c 111, s 30 [District Courts Act (1970)].

Ibid.

Judicature Act (1919), supra note 71, replaced the Supreme Court Act, supra note 63, in 1919. Consolidated Rules, supra note 72, rr 125, 517-18.

Royal Trust Corporation of Canada v Fillo (1981), 34 AR 174 at para 6 (QB) [Royal Trust]. 
the Rules of Court had been amended to prescribe where a trial should take place. If all the parties resided in the venue where the cause of action arose, the trial was to be heard in the nearest courthouse that held regular sittings. If a party was seeking a remedy including possession of land, the trial should be held in the courthouse nearest to the disputed land. ${ }^{82}$ These venue rules were retained when the Rules of Court were revised in $1968 .{ }^{83}$

\section{Alberta Court of QueEN's Bench}

The 1968 Rules of Court governed civil procedure in the Alberta Court of Queen's Bench from the time it was established in 1978 through to when the new Rules of Court took effect in 2010. The 1968 version of the Rules of Court, like its predecessors, dictated the location of trial but not where a matter should be commenced. For example, a plaintiff could file its pleadings at the Edmonton courthouse even though the pleadings contemplated that the trial should be held in Calgary. Any pre-trial applications would be heard in the venue where the pleadings had initially been filed, unless the Court ordered otherwise. ${ }^{84}$ Most matters were disposed of without a trial (for example, through default proceedings, settlement, discontinuances, or pre-trial motions), and therefore the rules governing the trial venue were usually moot. ${ }^{85}$ In interpreting these rules, the Alberta courts relied on the 1871 English case of Church $v$. Barnett and determined that plaintiffs had the right to start their actions in any venue they chose, as long as their choices were not "capricious." ${ }^{86}$ Courts characterized the right of a litigant to choose the venue in which to commence its action as something of importance that should not be set aside lightly. ${ }^{87}$

Defendants could apply to transfer a matter to a different venue. To succeed on such an application, a defendant would need to establish that the "preponderance of convenience" favoured the proposed venue. ${ }^{88}$ The court decisions on venue transfer applications focused on practical questions like where witnesses and key evidence were located as opposed to more abstract notions such as where a contract was formed or where mortgage payments were made.$^{89}$ The former considerations more directly impacted the costs and logistics of a court application or trial than did the latter.

In 1996, the Rules of Court were amended to add rule 6.1, which prescribed where an action should be commenced..$^{90}$ A plaintiff was required to start an action in the judicial centre that was closest to where all the parties resided or carried on business. If the parties were located close to different judicial centres, the plaintiff could pick at which one it would commence proceedings. ${ }^{91}$ Practitioners operating outside the major urban centres lobbied for

Alberta, Rules of the Supreme Court of Alberta, (1944), r 287; Alberta, Rules of the Supreme Court of Alberta (Consolidated, 1962), AR 561/57, r 287.

Rules of Court (1968), supra note 4, r 237.

Royal Trust, supra note 81 at para 14 (setting aside as an irregularity a motion brought in Edmonton on an action commenced in Peace River); Montreal Trust Co v 385070 Alberta Inc (1993), 10 Alta LR (3d) 201 (QB) [Montreal Trust Co].

Montreal Trust Co, ibid at paras 28-33.

Wade Investments, supra note 5 at para 3, citing Church v Barnett, supra note 5 at 119.

$C S \vee A J, 2004$ ABQB 73 at para 20 [CS].

Wade Investments, supra note 5 at paras 3-8.

See Van Horn v Coal Valley Systems Ltd (1987), 78 AR 203 (QB) at para 26; Montreal Trust Co, supra note 84 at para 43 .

Alberta Rules of Court Amendment Regulation (No 1), Alta Reg 243/96, s 3.

Rules of Court (1968), supra note 4, r 6.1(2)(c). 
this amendment. ${ }^{92}$ They were concerned the rules were "caus[ing] hardship to rural defendants, as well as loss of business for the rural Bar," because the rules only governed where a trial took place, and many matters were resolved at the pre-trial stage. ${ }^{93}$ The purpose of adding Rule 6.1 was to "make a lawsuit more convenient and fair for all parties ... by requiring a significant connection between the parties and the judicial district in which the action is commenced." ${ }^{94}$ Under Rule 6.1, plaintiffs could still choose between a few different venues, all of which would qualify as appropriate venues for commencing an action, but their choices were more restricted than under the pre-1996 rules. If the action was commenced in compliance with the rules, the plaintiff's choice of venue was entitled to deference, although it was still open to a respondent to argue that a venue transfer was appropriate. ${ }^{95}$

The Rules of Court no longer contain separate rules regarding the venue for commencing an action and for holding the trial. ${ }^{96}$ The Rules Project General Rewrite Committee determined that there was no justification for having two sets of rules. ${ }^{97}$ The current Rules of Court govern the venue where an action should be commenced and provide that the action should be carried out in that venue unless transferred. ${ }^{98}$ The new rules, discussed below, incorporate elements of the old rules, and case law decided under the old rules continues to be relevant to interpreting the new rules. ${ }^{99}$ However, decisions made prior to the enactment of Rule 6.1 in 1996 should be approached with caution.

\section{Alberta Provincial Court}

When Alberta became a province, it continued the practice - established when it was still a territory - of appointing magistrates to preside over minor legal disputes. ${ }^{100}$ In 1971, the legislature established the Provincial Court to replace the system of magistrates. ${ }^{101}$ When the Provincial Court Act was initially passed in 1971, it did not contain a venue rule. ${ }^{102}$ An expanded Provincial Court Act passed in 1978 did contain a venue rule, which prescribed that a matter should be commenced, carried on, and heard either in the venue where the defendant resided or carried on business or in the venue where the action arose. ${ }^{103}$ However,

Master Funduk noted that such lobbying occurred as early as the 1970 s and initially was not met with success: Montreal Trust Co, supra note 84 at paras 29-30.

Consultation Memorandum from June Ross, "Alberta Rules of Court Project: Commencement of Proceedings in Queen's Bench" (Edmonton: Alberta Law Reform Institute, 2002) at para 66, online: $<$ https://www.alri.ualberta.ca/docs/cm0121.pdf. $>$. See also Lim, supra note 23 at para 4. Apache Canada Ltd v Johnson, $2005 \mathrm{ABCA} 71$ at para 7 [Apache Canada].

Wickstrom $v$ Wetter, 2007 ABQB 402 at para 15.

Alberta Law Reform Institute, "Rules of Court Project: Final Report No 95" (Edmonton: Alberta Law Reform Institute, 2008) at Appendix G, online: <https://www.alri.ualberta.ca/docs/fr095.pdf $>$ [Alberta Law Reform Institute, "Final Report"].

Ross, supra note 93 at paras 75-83.

Rules of Court (2010), supra note 30, rr 3.3, 3.6.

325303 Alberta Ltd v Prime Property Management, 2011 ABQB 817 at paras 3-5 [325303 Alberta Ltd]. See also Darren J Reed \& Deborah Book, "Getting the Party Started - Recent Treatment of Part 3 (Court Actions) of the Rules of Court, Alta Reg 124/2010" in Rules of Court Interpreted (Edmonton: Legal Education Society of Alberta, 2012) at 1.

An Act Respecting Police Magistrates and Justices of the Peace, SA 1906, c 13.

The Provincial Court Act, SA 1971, c 86 [Provincial Court Act (1971)].

Ibid.

The Provincial Court Act, 1978, SA 1978, c 70, s 38 [Provincial Court Act (1978)]. Additionally, the 1978 legislation provided that where a defendant lived more than 30 kilometres from the place of a hearing, a plaintiff must deposit security to cover the defendant's travel expenses; however, this amount would only be paid to the defendant if the plaintiff did not succeed in proving its claims: Provincial Court Act (1978), ibid, s 40, re-enacted in Provincial Court Act, RSA 1980, c P-20, s 41. This provision was not included when the portion of the Provincial Court Act dealing with civil claims was re-enacted in a revised form by the Provincial Court Amendment Act, 1989, SA 1989, c 18, Part 4. 
only a year later, the venue rule was changed. The amended rule tasked the clerk with setting the hearing at the court location nearest to where the defendant resides or carries on business or where the action arose. ${ }^{104}$ An amendment passed in 2018 clarified that the trial and any pre-trial hearings should be scheduled by the clerk using these connecting factors. ${ }^{105}$

\section{RESIDENTIAL TENANCY TRIBUNAL}

The Residential Tenancy Tribunal was established as a temporary pilot program in Edmonton in 2006. ${ }^{106}$ A year later, in 2007, the provincial government permanently adopted the Tribunal and established a second location in Calgary. ${ }^{107}$ The legislation establishing the Residential Tenancy Tribunal was enacted in 2005 and has never contained a venue rule. The venue rules applicable to the Residential Tenancy Tribunal are set out in its Rules of Practice and Procedure, ${ }^{108}$ discussed below.

\section{Alberta’s Current Venue Rules}

Alberta's venue rules have changed over time. They also differ depending on the court or tribunal in which a litigant chooses to commence a legal proceeding: the Court of Queen's Bench, the Provincial Court, or the Residential Tenancy Tribunal. This section examines the venue rules applicable in all three systems, but the emphasis is on the venue rules in the Court of Queen's Bench. The focus on the Court of Queen's Bench reflects the doctrinal nature of this article. This article examines Alberta's procedural law as it appears "in the books": in legislation, regulations, and written decisions. There is significantly more doctrinal material articulating and interpreting the processes of the Court of Queen's Bench as compared to the Provincial Court or Residential Tenancy Tribunal. To better understand and critique the processes of these other two decision-making bodies, a researcher would need to study "law in action" - the informal rules created and sustained through the practices of the clerks, judges, and Residential Tenancy Officers who people these institutions.

The discussion of the Court of Queen's Bench Rules is divided between those governing where an action is commenced and those governing an application to transfer the venue.

The Attorney General Statutes Amendment Act, 1979 (No 2), SA 197 Provincial Court Civil Procedure Regulation, supra note 40, 2.
Residential Tenancies Amendment Act 2005 (No

Residential Tenancies Amendment Act, 2005 (No 2), SA 2005, c 46, s 3; Residential Tenancy Dispute Resolution Service Regulation, Alta Reg 98/2006, s 2; Mike Sadava, "New Home for Tenancy Disputes," Edmonton Journal (2 May 2006) B1. Although the Residential Tenancy Tribunal was established relatively recently, municipal Landlord and Tenant Advisory Boards have been around much longer. The Boards were not empowered to resolve disputes but could provide landlords and tenants with information and voluntary conciliation services: see Institute of Law Research and Reform, "Report No 22: Residential Tenancies" (Edmonton: University of Alberta, 1977) at 117-23, online: <https:// www.alri.ualberta.ca/docs/fr022.pdfs.

107 Darcy Henton, "Landlord Tenant Resolution Program Here to Stay,” Edmonton Journal (1 May 2007) B6.

108 Alberta, Residential Tenancy Dispute Resolution Service, Rules of Practice and Procedure (Service Alberta), online: < https://open.alberta.ca/dataset/65e3d06c-7a6e-40c9-8d30-e0aba219e4a1/resource/ be71b780-12a7-45a6-90f2-0b82dd27ac60/download/rpp-2019-01.pdf>, established pursuant to the Residential Tenancy Dispute Resolution Service Regulation, supra note 106, s 5. 


\section{A. Commencing An ACTion in the COURT OF QUEEN'S BENCH}

A plaintiff starting an action in the Alberta Court of Queen's Bench has the choice of filing in one of 11 different judicial centres. ${ }^{109}$ The Rules of Court dictate that a plaintiff should commence proceedings at the judicial centre which is closest to all the parties, as measured by road from each party's residence or place of business. ${ }^{110}$ Where a single judicial centre cannot be identified using this rule (for example, where the plaintiff resides close to the judicial centre of St. Paul and the defendant resides close to the judicial centre of Drumheller), the person starting the lawsuit selects the venue (either St. Paul or Drumheller). ${ }^{111}$ This set of rules tries to promote the hearing of matters in a location that is convenient to the parties - the underlying assumption being that it will be convenient to appear at the judicial centre near to where one lives or does business. ${ }^{112}$ The Rules also provide that, if the parties all consent, a matter may be heard at any one of the judicial centres in Alberta. ${ }^{113}$

Big businesses may carry on business in more than one place. For example, the Canadian Imperial Bank of Canada (CIBC) has branches in over 50 communities across the province. In such instances, the relevant place of business for identifying the appropriate venue is the place of business that is nearest to where "the matters in issue in the action arose or were transacted." $" 114$

The Court of Queen's Bench has considered how active a party must be in a location before it can be said to be carrying on business there. This question arose in a lawsuit started by a real estate developer against the specialized municipal district of Wood Buffalo, which is located in northeastern Alberta and includes the judicial centre of Fort McMurray. The dispute resulted from the development of land in that municipal district. ${ }^{115}$ Instead of starting the lawsuit in Fort McMurray, the real estate developer chose to sue 740 kilometres away in Calgary, where its head office and legal counsel were located. The developer took the position that it was entitled to start its action in Calgary because that was the only location in the province where it was carrying on business. The Court found that the developer was also carrying on business in Fort McMurray and, therefore, should have commenced the action there.

The Rules of Court (2010), supra note 30, use the term "judicial centre" and define it in the Appendix. The Judicial Districts Regulation, Alta Reg 117/2010, passed pursuant to the Court of Queen's Bench Act, RSA 2000, c C-31, s 23 identifies 11 judicial districts and sets their boundaries. Additionally, the Court of Queen's Bench has two circuit locations, in Hinton and High River: Court of Queen's Bench of Alberta, "Locations and Sittings Map" (CQBA, 2017), online: < https://albertacourts.ca/qb/about/ locations-and-sittings $>$.

Rules of Court (2010), ibid, r 3.3(1)(a). A decision under the predecessor to the current rules held that the time for determining the place of residence of the parties was when the legal proceedings were commenced and not when the cause of action arose: Ferguson $v$ Rubik, 2002 ABQB 779 at para 9. Rules of Court (2010), ibid, r 3.3 .

112 George Neff Stevens, "Venue Statutes: Diagnosis and Proposed Cure" (1951) 49:3 Mich L Rev 307 at 311-13.

Rules of Court (2010), supra note 30, r 3.3(3).

Ibid, r 3.3(2).

Pacific Investments \& Development Ltd v Wood Buffalo (Region), 2017 ABQB 469 [Pacific Investments]. 
To determine if the plaintiff was carrying on business in Fort McMurray, the Court considered the "structure of [the plaintiff] corporation's operations, the nature of the issues in the lawsuit, and the relationship between the parties in respect of those issues." 116 The Court found that there was "a significant connection between [the plaintiff] and Fort McMurray" on the basis that the lawsuit related to land that the plaintiff was developing near Fort McMurray, the plaintiff owned other land nearby, and the plaintiff's representatives visited Fort McMurray periodically as part of their development activities. ${ }^{117}$ Based on the strength of this connection, the Court concluded that the plaintiff was carrying on business in Fort McMurray. The principal defendant, such as the specialized municipal district of Wood Buffalo, was also carrying on business in and around Fort McMurray, and so the appropriate venue in which to commence the proceedings was Fort McMurray. ${ }^{118}$

Similarly, in a contractual dispute between a plaintiff property owner and the company it hired to manage its properties, the Court held that the plaintiff carried on business in Grande Prairie because it had employees there, and the dispute related to the management of properties located in Grande Prairie and the nearby community of High Prairie. ${ }^{119}$

The Court has provided a framework for determining where a party carries on business, but less is said in these decisions about the second part of the venue rule applicable to litigants with multiple locations, namely how to identify where the "matters in issue ... arose or were transacted." ${ }^{20}$ In fact, the case law has integrated the "nature of and issues in the lawsuit" into the test for where a party can be said to carry on business. ${ }^{121}$

Failure to start an action in an appropriate judicial centre is not fatal to the action. ${ }^{122}$ Rather, the plaintiff's failure to start an action in an appropriate judicial district affects which party has the onus if a defendant applies for a transfer. ${ }^{123}$ If the applicant (defendant) can show that the plaintiff failed to comply with the rules about where to start the action, the plaintiff bears the onus of showing that its choice was nonetheless reasonable. Conversely, if the plaintiff complied with the commencement rules, the defendant bears the onus of showing that continuing in the chosen judicial district would be unreasonable. A plaintiff who starts an action in the wrong jurisdiction may be subject to an adverse costs award. ${ }^{124}$

Ibid at para 31. See also 325303 Alberta Ltd, supra note 99 at para 17, citing Apache Canada, supra note 94 at para 7.

Pacific Investments, ibid at para 33.

The real estate developer also sued the Chief Administrative Office of the specialized municipal district. This individual's residence was located in Victoria, British Columbia, but formerly had been located in Fort McMurray, Alberta (ibid at paras 9, 30).

325303 Alberta Ltd, supra note 99 at paras 24-26.

Rules of Court (2010), supra note 30, r 3.3(2).

Pacific Investments, supra note 115 at para 33.

The Honourable William A Stevenson \& The Honourable Jean E Côté, Civil Procedure Encyclopedia, vol 1, ed by Debra MacGregor et al (Edmonton: Juriliber, 2003) at 23-7 to 23-8, citing Normandeau v PBS Builders Inc (1986), 42 Man R (2d) 31 (CA); Lim, supra note 23 at para 14. The old rules were explicit on this point: Rules of Court (1968), supra note 4, r 6.1(4). See Tuckanow v Bowden Penitentiary, 2014 ABQB 563 at paras 20-23, where the plaintiff improperly started an action in Edmonton but was allowed to continue it on the basis that the defendant consented to that venue.

Odland v Odland, 2017 ABCA 397 at para 19 [Odland]; Sobeys Capital Incorporated v Gulf \& Pacific Equities Corp, 2018 ABQB 151 [Sobeys Capital].

One of the factors courts can consider in deciding to award costs is any "contravention of or noncompliance with [the Rules of Court]": Rules of Court (2010), supra note 30, r 10.33(2)(f). Discussing the predecessor to the current rules, see Lim, supra note 23 at para 17. In Pacific Investments, supra note 115 at para 51, the Court upheld a finding by the Master that the action had been started in the wrong venue and awarded Schedule C costs against the plaintiff. In 325303 Alberta Ltd, supra note 99 at paras 
A defendant in such an action may also be able to seek compensation for any harm suffered as a result of the improper venue choice. For example, where the litigation relates to a consumer transaction, the defendant may be able to claim compensation on the basis that suing in the wrong venue amounts to an unfair practice under the Consumer Protection Act. ${ }^{125}$ If it can be established that the plaintiff's counsel ignored the venue rules, the Law Society could censure the conduct as amounting to unethical practice. ${ }^{126}$

\section{B. Changing the Venue in the COURT OF QUEEN'S BENCH}

Once an action has been commenced, there are several mechanisms available to transfer the action - a general transfer rule, an expedited process for transferring actions against land, and a rule that specifically relates to enforcement proceedings.

\section{GENERAL TRANSFER RULE: COURT OF QUEEN'S BENCH}

The general transfer rule provides that an action can be transferred to a different judicial centre if the parties request such a transfer or if the Court thinks it would be unreasonable to proceed with the action at its current location. ${ }^{127}$ A party contesting the venue must file an application in the judicial centre where the claim has been commenced and prepare a written affidavit containing the evidence that suggests a transfer is warranted. Unless the other side consents to the transfer, the party must attend a hearing in the original venue to argue the merits of its application. Courts do have jurisdiction to transfer an action on their own initiative; however, they would need to have the issue of venue brought to their attention and be satisfied that there was sufficient evidence to justify a transfer of the matter. ${ }^{128}$

Courts have interpreted the "unreasonableness" threshold to mean that an application to transfer an action should be granted when the balance of convenience favours the proposed venue over the existing one. ${ }^{129}$ This standard remains unchanged from the pre-2010 rules. ${ }^{130}$

28-29, the Court held that the plaintiff should have commenced its proceeding in Grande Prairie, not Edmonton, and awarded the defendant costs in any event of the cause. See also Ross, supra note 93 at paras 87-90. The revised rules, however, are not as explicit as the old rules on this point: see Alberta Rules of Court (1968), supra note 4, rr 6.1(4)-(5). In the model venue statute that he drafted for American states, Stevens recommended that a defendant who successfully challenges the venue selected by the plaintiff should be awarded "reasonable compensation for defendant's trouble and expense, including attorney's fees, in attending in the wrong county" (supra note 112 at 336).

Rosen notes there are American precedents that would support such a claim (supra note 24 at 539). Under the Consumer Protection Act, RSA 2000, c C-26.3, s 6(2)(b), unfair practices are defined very broadly and include taking advantage of a "consumer's inability to understand the character, nature, language or effect of the consumer transaction or any matter related to the transaction." The Consumer Protection Act, s 13, creates a right to compensation when an individual suffers harm as a result of an unfair practice. The Consumer Protection Act is unlikely to apply to mortgage default proceedings or eviction applications due to how the legislation defines "consumer transaction": s 1(1)(c). Stevenson \& Côté, supra note 122 at 23-14, citing Law Society of Alberta \& Canadian Bar Association Alberta Branch Newsletter 11:5 (November 1986). Rules of Court (2010), supra note 30, r 3.5 .

In two cases decided under the old rules, the Court noted that "[it] is entitled to govern [its] own proceedings and insure the rules are being complied with": Lim, supra note 23 at para 14, cited with approval in National Holdings, supra note 22 at paras 4-5. Nothing in the revised venue rules suggests that the Court has been stripped of this power. 
There has been some case law suggesting that a higher threshold must be met, namely that the applicant must establish that it would be capricious, arbitrary, or irrational to continue proceedings in the existing venue; however, the preponderance of authority rejects this higher threshold. ${ }^{131}$ As discussed in the previous section, the onus on an application to transfer an action rests with the applicant (defendant), unless the applicant can show that the plaintiff did not comply with the venue rules when it commenced its action. ${ }^{132}$

In establishing which location the balance of convenience favours, courts will consider the following factors:

- The number of parties or witnesses in each judicial centre;

- The nature of the issues in the lawsuit;

- The relationship between the parties in respect of those issues;

- The parties' respective financial resources; and

- The stage of proceedings. ${ }^{133}$

Courts will consider, but give "lesser weight" to these additional factors:

- The convenience of location for pre-trial motions; and

- The location of relevant assets. ${ }^{134}$

The location of a party's chosen counsel should not be "a decisive factor" in the balance of convenience test ${ }^{135}$ - although, it may be given some weight if the other factors are evenly balanced. ${ }^{136}$ The justification for not putting weight on " $[t]$ he factor of inconveniently located counsel" is that it "only arises because of a choice by a party and [the party] should not gain by that choice." "137

Unlike the post-1996 Rules of Court, the new rules no longer have separate provisions governing where an action should be commenced and where a trial should be heard. Nonetheless, courts still recognize that the balance of convenience may shift over the course of a lawsuit. In a dispute over the division of matrimonial property, the Court refused to transfer the proceedings to Fort McMurray at the pre-trial stage but recognized that the balance of convenience may shift if the matter reached a stage where witness testimony was required, as most of the relevant witnesses lived in Fort McMurray. ${ }^{138}$ Likewise, one can imagine a similar shift occurring when a plaintiff's goal progresses from trying to get a

Regular v Regular, 2016 ABQB 570 at paras 6-7 [Regular]; Pacific Investments, ibid; Sobeys Capital, supra note 123 at paras $17-18$.

Odland, supra note 123 at para 19; Regular, ibid at para 5.

Regular, ibid at para 9, cited with approval in Odland, ibid at para 21; Pacific Investments, supra note 115 at para 39.

Regular, ibid, cited with approval in Odland, ibid; Pacific Investments, ibid at para 40. Odland, ibid at para 22; Regular, ibid at para 8; Pacific Investments, ibid at para 38.

Stevenson \& Côté, supra note 122 at 23-5, citing Nescorp Resources Inc v Color Your World Corp, [1994] AJ No 1281 (QL) (QB).

Anderson v Kent, 1981 ABCA 242 at para 3, cited with approval in Christensen v Proprietary Industries Inc, $2002 \mathrm{ABQB} 97$ at para 61 [Christensen].

Regular, supra note 131 at paras $2,14,18$. In Christensen, ibid at para 72 , which was decided under the old rules, the Court granted a venue change application but directed that it should only take effect once the matter was scheduled for trial. 
judgment to enforcing that judgment. For example, it may be more convenient to have any writ enforcement applications heard near to where the debtor's assets are located.

When a legal dispute relates to real property, courts give weight to the location of the property when applying the balance of convenience test. In a case where a bank had started foreclosure proceedings in Edmonton against a widow located in Calgary, the Court directed a transfer of the file to Calgary on the basis that the residence in question was located there. ${ }^{139}$ In the real estate developer's lawsuit against the specialized municipal district of Wood Buffalo, the Court found that the balance of convenience test favoured continuing the lawsuit in Fort McMurray instead of Calgary. The Court put significant weight on the fact that the dispute pertained to land located near Fort McMurray. The Court cited the location of the land both when applying the "issues in the lawsuit" consideration and the "location of relevant assets" consideration. ${ }^{140}$ The emphasis courts put on the location of real property when deciding the proper venue is relevant to the three types of proceedings discussed in this article, all of which involve legal contests relating to real property.

Prior to the 2010 rules being enacted, Alberta courts refused to put weight on a litigant's financial capacity when deciding where a matter should be adjudicated. As Master Funduk put it in a 1989 decision, the Court would not force "the wealthier litigant [to] litigate in the backyard of the poorer litigant." 141 In a break from this previous case law, courts now recognize that the relative financial capacity of litigants is a proper concern when deciding applications regarding venue. In Abou-Morad v Aboumourad, the Court was asked to transfer the venue of divorce proceedings from Edmonton to Fort McMurray. ${ }^{142}$ The wife, a resident of Fort McMurray, alleged that she earned significantly less than her husband, who resided and had commenced the action in Edmonton. In dismissing the application, the Court noted that the wife's financial position remained a factually contested matter. ${ }^{143}$ In other words, the Court recognized that financial disparity can matter but held that it remained unproven in this case. Subsequently, the litigants' financial capacity was incorporated into the list of factors a court should consider when asked to transfer an action. A litigant's financial capacity may not be determinative, because it is just one of seven factors a court is directed to balance, but the courts' willingness to consider this factor indicates that the substantive law on venue has evolved to make space for judges to adopt an access to justice ethos.

\section{EXPEDITED TRANSFER PROCESS: COURT OF QUEEN's BENCH}

There is a long history in both England and Alberta of special venue rules applying when litigation involves real property. As discussed in the previous section, Alberta courts put weight on the location of real property when asked to transfer a matter. Additionally, the Rules of Court provide an expedited method for transferring proceedings if a plaintiff starts 
an action by way of statement of claim seeking "possession of land."144 The defendant can have the action transferred to the judicial centre closest to the land or the defendant's residence simply by filing a form with the clerk of the court and serving it on the other parties to the litigation. The other parties have ten days to object to the transfer. If an objection is filed, the Court must adjudicate the dispute. Absent a timely objection, the defendant can have the clerk transfer the matter without a court application. ${ }^{145}$ This venue transfer provision was included in the revised Rules of Court in response to concerns raised by the rural Bar about foreclosure actions being commenced in judicial centres other than where the land at issue was located. ${ }^{146}$ One reason this expedited transfer process was limited to claims "seeking possession of land" is because of the relative ease of identifying the location of land. In other types of actions, the factors connecting the claim to a particular location may be more difficult to ascertain. ${ }^{147}$

Default proceedings on mortgages will be started by a statement of claim, will seek possession of land, and, consequently, will be subject to this expedited transfer process. ${ }^{148}$ The exception to this rule is where a lender is only seeking a monetary judgment against the defendant borrower. ${ }^{149}$ A previous iteration of the venue rule had a provision that applied to actions claiming "possession of land," and the Court held that this provision did not apply to mortgage default proceedings where a plaintiff was only seeking a monetary judgment. ${ }^{150}$ This reasoning would likely preclude defendants from using the expedited transfer process in a mortgage default proceeding where the only relief a lender seeks is monetary in nature.

When landlords choose to bring eviction applications in the Court of Queen's Bench, they may do so using a different commencement document, an originating notice. ${ }^{151}$ Even though the landlords are seeking vacant possession of land, they do not necessarily start their claim by way of a statement of claim. Consequently, tenants facing eviction proceedings may not have recourse to the expedited transfer process.

Defendants in writ enforcement proceedings may not be able to take advantage of the expedited process, because the underlying judgment may be unrelated to land. If a plaintiff sues a defendant for committing a tort or breaching a contract, the statement of claim will likely seek remedies including damages and costs, but not possession of land. The proceedings only become related to land once the Court grants judgment and the successful

Rules of Court (2010), supra note 30, r 3.4. Under the old rules, a trial regarding the possession of land was to be heard in the judicial district where the land was located: Rules of Court (1968), supra note 4, r 237, and when deciding the appropriate venue for pre-trial matters, Alberta courts recognized that "special rules relating to the venue may apply where the litigation is in rem litigation relating to land": CS, supra note 87 at para 18 .

Twohig \& Pawson noted in 1997 that a similar, expedited process for venue transfer was being employed in the United Kingdom: supra note 49 at 153.

Ross, supra note 93 at paras 65-68, 72. The rural Bar was concerned with both the "hardship to rural defendants, as well as loss of business for the rural Bar": ibid at para 66.

Ibid at para 87.

"Land" is defined in the Appendix to the Rules of Court (2010) as "real property" and therefore would include such holdings as an ownership interest in a condominium. Applications are started by statement of claim, unless one of the exceptions in the Rules of Court (2010), ibid, r 3.2(2) applies, in which case they are started by originating application.

First Investors Corp v Golden Flow Developments Ltd (1981), 17 Alta LR (2d) 395.

Price \& Trussler, supra note 7 at 33; Barber, supra note 1 at 221.

Rules of Court (2010), supra note 30, r 3.2(2)(d); RTA, supra note 32, s 41, Mobile Home Sites Tenancies Act, supra note $34, \mathrm{~s} 43$. 
judgment creditor takes steps to enforce the writ against the judgment debtor's property by serving the judgment debtor with a document called a notice of intention to sell land. ${ }^{152}$

The defendant's ability to use the expedited process for changing the venue is timelimited: the form must be filed with the Court before the close of pleadings. ${ }^{153}$ The close of pleadings occurs once the basic pleadings in a lawsuit have been filed at the courthouse and served on the adverse parties. The term "close of pleadings" is defined in contemplation of a lawsuit commenced by a plaintiff filing and serving a statement of claim. ${ }^{154}$ The defendant then asserts any defences in a statement of defence. ${ }^{155}$ Upon receiving the statement of defence, the plaintiff has a chance to respond by filing a reply. ${ }^{156}$ The plaintiff must file the reply and serve it on the defendant within ten days of having been served with the statement of defence. ${ }^{157}$ Pleadings close either when a timely reply is filed and served or, in the absence of a court order or agreement of the parties otherwise, when the ten days for filing and serving a reply elapses. ${ }^{158}$

The time limit applicable to the expedited transfer process has the potential to create confusion. Many self-represented litigants may be unfamiliar with the concept of the close of pleadings. Additionally, it is unclear how the time limit should apply in mortgage default proceedings. Defendants in mortgage default proceedings often file a demand for notice instead of a statement of defence. ${ }^{159}$ By filing a demand for notice, the defendant concedes liability but reserves the right to speak to the appropriate remedy. ${ }^{160}$ The Rules of Court do not contemplate pleadings closing where a demand for notice is filed instead of a statement of defence. Consequently, a defendant in mortgage proceedings might take the position that it has recourse to the expedited transfer process up until the time the proceedings are concluded.

\section{TRANSFER PROCESS FOR WRIT PROCEEDINGS: COURT OF QUEEN's BENCH}

The final rule for transferring proceedings allows a judgment creditor to apply for a temporary transfer of proceedings after judgment has been granted. ${ }^{161}$ This rule is of little assistance to the judgment debtor facing writ enforcement proceedings against their house - because it is only available to judgment creditors. Moreover, it requires an application to court for an order transferring the action, and so it is unclear what this provision adds to the general ability of the Court to transfer actions other than that it allows for a temporary, as opposed to a permanent, transfer of an action.

CEA, supra note $37, \mathrm{~s} 70$.

Rules of Court (2010), supra note 30, r 3.4(3)(a).

See ibid, r 3.2(1).

See ibid, r 3.30.

Ibid, r 3.33, Form 20.

Ibid, r 3.33(3).

Ibid, $\mathrm{r} 3.67$.

Ibid, $\mathrm{r} 3.34$.

For example, the defendant may ask for a longer redemption period or resist the plaintiff's attempts to shorten it. The redemption period is a block of time during which the mortgage default proceedings are stayed. During the redemption period, the defendant may sell the property itself or cure the default under the mortgage. In Alberta, the presumptive redemption period is one year for farmland and six months for other land: LPA, supra note 30, s 41.

Rules of Court (2010), supra note 30, r 3.7. 


\section{Venue Rules: The Provincial Court}

The Provincial Court has locations in 72 communities across Alberta. ${ }^{162}$ Only 18 of these locations regularly hold civil court sittings. ${ }^{163}$ Civil claims brought in the Provincial Court are governed by the rules set out in Part 4 of the Provincial Court Act and the recently passed Provincial Court Civil Procedure Regulation. Where the legislation is silent, the Rules of Court can be applied or applied in a modified form, where "necessary to ensure an expeditious and inexpensive resolution of a matter." 164

The Provincial Court Civil Procedure Regulation provides that the clerk of the Provincial Court should schedule a pre-trial hearing or trial at the courthouse that is closest either to where the defendant resided (or carried on business) at the time the Court issued the civil claim or to where the cause of action arose. ${ }^{165}$

The Provincial Court can change the location of the hearing at the initiative of a judge or in response to an application by one of the parties. ${ }^{166}$ The author was unable to locate any written decisions interpreting this provision. ${ }^{167}$ In deciding a transfer application, a Provincial Court judge may take account of the list of factors identified by the Court of Queen's Bench in its written decisions, including the financial capacity of the litigants. ${ }^{168}$

If a party succeeds in their matter and wishes to file the resulting judgment at the Court of Queen's Bench for the purposes of enforcing it, they must file the judgment at the judicial centre of the Court of Queen's Bench that is closest, by road, to the Provincial Court location where the judgment was granted. ${ }^{169}$

\section{Venue Rules: Residential Tenancy Tribunal}

The Residential Tenancy Tribunal has locations in Edmonton and Calgary. Claims brought before an officer of the Residential Tenancy Tribunal are governed by the Residential Tenancies Act and related regulations. ${ }^{170}$ Additionally, the Residential Tenancy Tribunal has

As listed on its website: Provincial Court of Alberta, "Locations Map" (PCA, 2017), online: $<$ https://albertacourts.ca/pc/court-practice-and-schedules/locations-map $>$. In total, 73 locations are listed but two are in the City of Red Deer. The Sittings of the Provincial Court Regulation, Alta Reg 144/80, Schedule I lists 101 communities in which sittings of the Provincial Court will be held.

As listed on its website: Provincial Court of Alberta, ibid. The locations that are listed as holding regular civil court sittings are Calgary, Drumheller, Edmonton, Fort McMurray, Fort Saskatchewan, Grande Prairie, High Level, Hinton, Leduc, Lethbridge, Medicine Hat, Peace River, Red Deer, Sherwood Park, St. Albert, St. Paul, Stony Plain, and Wetaskiwin.

PCA, supra note 40, s 8(2). Even before they were expressly authorized to do so by legislation, Provincial Court judges found they could apply the venue rules in the Rules of Court to Provincial Court proceedings: see RFB v TLB (1990), 105 AR 67 (PC).

Provincial Court Civil Procedure Regulation, supra note 40, s 16, previously Provincial Court Civil Division Regulation, supra note 40, s 2.

Provincial Court Civil Procedure Regulation, ibid, s 17, previously PCA, supra note 40, s28, previously Provincial Court Act, RSA 1980, c P-20, s 40 [PCA (1980)].

As of 8 January 2019, no relevant cases were identified by noting up Provincial Court Civil Procedure Regulation, ibid, and PCA, ibid, in Westlaw, Quicklaw, and CanLII or by noting up PCA (1980), ibid, in Westlaw.

See supra note 133-34 and accompanying text.

Provincial Court Civil Procedure Regulation, supra note 40, s 36, previously Provincial Court Civil Division Regulation, supra note 40, s 3.

Residential Tenancy Dispute Resolution Service Regulation, supra note 106. 
adopted Rules of Practice and Procedure. ${ }^{171}$ The Rules of Practice and Procedure stipulate that an application for a hearing can be filed in person at the Tribunal's Edmonton or Calgary offices, online, or by mail or fax. ${ }^{172}$ Hearings relating to rental premises located in Edmonton are held in Edmonton; hearings relating to rental premises located in Calgary are held in that city; when the rental premises are located outside of these two metropolitan areas, the hearings are held by telephone. ${ }^{173}$

\section{E. REMOTE APPEARANCES}

Technology provides one method for overcoming the geographic barriers to access to justice; however, it is not always a panacea for self-represented litigants. Consider the provision in the Rules of Court that empowers clerks to accept documents that have been filed electronically — by facsimile or email. ${ }^{174}$ In practice, Court of Queen's Bench clerks may only accept documents filed electronically if the filing party is located in a different judicial district, they may only accept documents filed by facsimile (not email), and they may only accept documents from a party who has an account with the Court. This last requirement ensures that a party pays the filing fee prior to a document being filed, but it also precludes electronic filing by most self-represented litigants. Similarly, the Rules of Court governing remote appearances seem promising on their face, but prove difficult to use in practice.

Remote appearances, by telephone or video link, allow individuals to take part in a court application despite being a long distance away from the location of the hearings. ${ }^{175}$ During the revision process, which preceded the new Rules of Court coming into force in 2010, the members of the Rules of Court Committee considered the availability of telephone hearings. ${ }^{176}$ Under the pre-revision rules, litigants could apply to appear electronically if they were located more than 100 kilometres from the courthouse where the matter was to be heard. Additionally, the Court had the discretion to allow an electronic hearing in any situation it felt was appropriate. ${ }^{177}$ The Rules of Court Committee endorsed telephone applications as being convenient and cost-effective and were of the view that a court should allow for a telephone hearing when a party lived or worked more than 50 kilometres from where the application was to be heard. ${ }^{178}$

The revised Rules of Court provide that an application or a trial can be heard electronically and contemplate one or more parties appearing by telephone, video link, or other electronic

$171 \quad$ Supra note 108.

$172 \quad$ Ibid at 6.

173 Ibid at 20; Service Alberta, "Residential Tenancy Dispute Resolution Service Hearings," online:

$<$ https://www.alberta.ca/rtdrs-hearings.aspx>; Service Alberta, "Location Charts: Residential Tenancy Dispute Resolution Service," online: <https://open.alberta.ca/dataset/c16390a8-4a10-40c6-a89b-607d 2d0d095e/resource/fc126eb9-fb00-479b-94f6-7969ceb09076/download/location_charts.pdf>. Rules of Court (2010), supra note 30, r 13.41(2)(c).

175 For a cross-Canada study of the use of video and audio conferencing, see Jane Bailey, "Digitization of Court Processes in Canada" (2014) Laboratoire de Cyberjustice Laboratory Working Paper No 2 at 13-18, online: <www.cyberjustice.ca/files/sites/102/WP002_CanadaDigitizationOfCourtProcesses2012 1023.pdf $>$.

176 Consultation Memorandum from Debra Hathaway, “Alberta Rules of Court Project: Motions and Orders" (Alberta Law Reform Institute, 2004) at paras 22-42, online: <https://www.alri.ualberta.ca/ docs/cm01210.pdf>.

177 Alberta Rules of Court (1968), supra note 4, rr 385.1, 385.2.

178 Hathaway, supra note 176 at para 31. 
means. ${ }^{179}$ The 50-kilometre pre-condition to appearing electronically did not make it into the final version of the Rules, but court approval is required before a matter can be heard electronically. ${ }^{180}$ Consequently, a party wishing to have a matter heard electronically must bring an application seeking this relief. The Rules further provide that the Court can direct that it will conduct an electronic hearing when deciding whether or not to hear the application electronically. Essentially, this means that an applicant must write to the Court asking to appear electronically, so that it can argue that its transfer application should be heard electronically. ${ }^{181}$

Electronic hearings are regularly used in mortgage default applications outside of the Edmonton and Calgary areas, with lawyers for the foreclosing lenders appearing by telephone. These lawyers are familiar with the process for requesting an electronic hearing of their matter. The two-step process - applying for leave to appear electronically and then writing to arrange for an electronic hearing of their application - does not pose an obstacle to them. But some of these lawyers report that the willingness of courts to grant permission for electronic appearances varies from courthouse to courthouse. For a self-represented litigant who is unfamiliar with legal practice, the two-step process for having a matter heard electronically is needlessly complex and difficult. Layer onto this complex process the possibility that courts in different communities may be inconsistent in their approach to granting permission to appear electronically, and there is a real likelihood that selfrepresented litigants trying to appear remotely may be thwarted.

Despite the potential difficulties of appearing electronically, the possibility that a litigant could do so has factored into how the Court of Queen's Bench applies its venue rules. For example, in the case of Regular, the Court denied a spouse's application to transfer a matter from Edmonton to Fort McMurray, where the applicant resided. ${ }^{182}$ The next step contemplated in the litigation was a summary judgment hearing. In weighing which location was favoured by the balance of convenience test, the Court noted that the applicant could "listen in by telephone," 183 rather than travel to Edmonton for the hearing. In the case of C.S. v. A.J., decided under the old Rules, the Court denied a venue change application in a custody dispute, where the next step in the matter would be a special chambers application. ${ }^{184}$ The Court noted that it "encourages the use of contemporary technology wherever possible and would certainly hear a special chambers application by telephone if counsel wished to make submissions in that way." 185

Regulations passed in 2018 under the Provincial Court Act copy the provisions in the Rules of Court pertaining to electronic hearings. ${ }^{186}$ Prior to this, the Provincial Court Act and

Rules of Court (2010), supra note 30, rr 6.9, 6.10, 8.18; Alberta, Court of Queen's Bench of Alberta, Civil Practice Note 1: Applications Without Personal Appearance, online: <https://alberta courts.ca/docs/default-source/qb/civil-practice-note-1---applications-without-personal-appearance.pdf>. An appeal can also be heard electronically: Rules of Court (2010), ibid, r 14.73(f).

An example of where the court may decline to hear a matter by telephone is if the matter is complex and better suited to a special chambers application: Hoff v Gerk, 1999 ABQB 744 at para 24.

Rules of Court (2010), supra note 30, r 6.10(3)(a).

Supra note 131.

Ibid at para 16. See also Abou-Morad, supra note 142 at para 2.

Supra note 87.

Ibid at para 34

Provincial Court Civil Procedure Regulation, supra note 40, s 22. 
accompanying regulations were silent on the topic, but telephone hearings were commonplace.

At the Residential Tenancy Tribunal, parties can appear by telephone as long as they provide notice to the Tribunal at least 60 minutes prior to a hearing. ${ }^{187}$ Additionally, hearings related to rental premises located outside of the Edmonton and Calgary areas are conducted entirely by telephone. ${ }^{188}$

When parties are able to use technology, it may provide greater access to the court system, but a few notes of caution must be sounded. First, the ability to participate electronically may not always be available to individuals. They may lack the requisite technology at home, or the Court may not have the necessary services to support an electronic appearance. In Keaton v. Keaton, a 2017 decision of the Alberta Court of Queen's Bench, the presiding justice noted that "the Court administration in Red Deer does not have the capacity to hear counsel by telephone and requires personal appearance." ${ }^{189}$ It is unclear from this statement whether the Red Deer Court was incapable of facilitating any remote appearances, or merely chose not to extend this option to counsel but would make it available to self-represented litigants. Second, appearing electronically is not the same as appearing in person. A defendant appearing electronically is physically separated from the plaintiff's counsel and the judge, who are together in the courtroom. ${ }^{190}$ This set-up may result in defendants feeling excluded from the process and may hinder their ability to present their cases. ${ }^{191}$ Opposing counsel and judges might treat defendants appearing remotely differently than those appearing in person. For example, the technology used may impede credibility assessments or impair the emotional connection between the remote participant and the personnel present in the courtroom. ${ }^{192}$ Giving a party the option to appear remotely is preferable when the alternative is that the party cannot appear at all, but when faced with an application to transfer a matter, courts need to recognize that the possibility of remote participation is not equivalent to the opportunity to attend in person. Likewise, legislators need to recognize that the possibility of a remote appearance is not a complete antidote to venue rules that are unfair in substance or in practice.

\section{Potential Reforms}

Alberta's venue rules have come a long way since the Reddicks applied to have their mortgage default proceedings transferred from Edmonton to Calgary. Today, a court would

Rules of Practice and Procedure, supra note 108 at 14.

Ibid at 20 .

2017 ABQB 429 at para 2.

Jane Bailey, Jacquelyn Burkell \& Graham Reynolds, “Access to Justice for All: Towards an 'Expansive Vision’ of Justice and Technology” (2013) 31:2 Windsor YB Access Just 181 at 202-204.

Amy Salyzyn, "A New Lens: Reframing the Conversation about the Use of Video Conferencing in Civil Trials in Ontario" (2012) 50:2 Osgoode Hall LJ 429 at 449.

Ibid at 443-50. The shortcomings of remote appearances have also been considered in the case law applying sections 486.2 and 714.1-714.8 of the Criminal Code of Canada, RSC 1985, c C-46, which allow witnesses to appear by video or telephone: see e.g. $R v$ Hinkley, 2011 ABQB 567. On the other hand, "[p]articipating comfortably in one's home may reduce anxiety or logistical hurdles for those with mental health issues or physical disabilities," and technology may facilitate the resolution of disputes in the context of an entirely online system where both parties are participating remotely because the technology obscures the "[a]ntagonistic body language" that is anathema to compromise: Salter, supra note 15 at 126. 
likely allow the transfer, but only if the Reddicks knew that a venue transfer was available and knew how to ask for it. ${ }^{193}$ The content of Alberta's venue rules has evolved to better ensure that defendants will be able to appear at proceedings that may result in the loss of a home. This evolution has been driven by the changing nature of litigation. Self-represented litigants have become commonplace in Alberta courts. In a 1993 decision, Master Funduk noted that parties appearing in mortgage default procedures were always represented by counsel, ${ }^{194}$ whereas by 2013 Master Schlosser noted that it was not unusual for selfrepresented litigants to appear in mortgage default proceedings. ${ }^{195}$ Although there are a number of reasons why litigants might end up representing themselves, many lack the financial resources necessary to retain counsel. ${ }^{196} \mathrm{~A}$ litigant with limited financial resources may also be unable to participate in legal proceedings when they take place far away from the litigant's home. The venue rules in the Court of Queen's Bench now take account of a litigant's financial capacity whereas previously courts had declined to consider the relative resources of the parties when deciding transfer applications. ${ }^{197}$ The content of the rules would still benefit from a few adjustments, but it is the process required to invoke these rules that creates serious hurdles to self-represented litigants. These procedural hurdles must be addressed, especially in the Court of Queen's Bench, or the venue rules risk being unfair in practice.

The reforms to the content of the rules outlined below pertain to the Court of Queen's Bench and Provincial Court. No recommendations are made regarding the content of the Residential Tenancy Tribunal's venue rules because they are already designed to facilitate participation by the tenant: proceedings are either held in the venue where the residential premises (and presumably, in most cases, the tenant) are located or by telephone. ${ }^{198}$ The reforms to the related practices focus on the Court of Queen's Bench and are informed by the author's experiences providing legal assistance to self-represented litigants appearing in morning chambers at the Court of Queen's Bench. These reforms to related practices may have application in the Provincial Court and the Residential Tenancy Tribunal, but it is impossible to opine with certainty until further "law in action" research is carried out at these decision-making bodies.

Reddick, supra note 2. Transfers have been allowed in similar cases: see Nemeth, supra note 22; National Holdings, supra note 22; Lim, supra note 23. Additionally, the Reddicks would have been able to use the expedited transfer process.

Nemeth, supra note 22 at para 10.

Julie Macfarlane, "The National Self-Represented Litigants Project: Identifying and Meeting the Needs of Self-Represented Litigants Final Report" (2013) at 38-44, online: Representing Yourself Canada $<$ https://representingyourselfcanada.com/wp-content/uploads/2016/09/srlreportfinal.pdf $>$; Stratton, supra note 16 at $89-90$.

Deadmarsh, supra note 141 . The contemporary cases are cited at supra note 133.

There are many other areas of the Residential Tenancy Tribunal's practice that would benefit from reform: see e.g. Jonnette Watson Hamilton, "For Shame: An Obvious and Fundamental Breach of Natural Justice by the Residential Tenancies Dispute Resolution Service (RTDRS)" (19 January 2016), ABlawg (blog), online: <https://ablawg.ca/2016/01/19/for-shame-an-obvious-and-fundamental-breachof-natural-justice-by-the-residential-tenancies-dispute-resolution-service-rtdrs/>; Jonnette Watson Hamilton, "Don't Think Twice: The Residential Tenancies Dispute Resolution Board's Power to Correct for Procedural Unfairness" (1 March 2016), Ablawg (blog), online: <https://ablawg.ca/2016/ 03/01/dont-think-twice-the-residential-tenancies-dispute-resolution-boards-power-to-correct-forprocedural-unfairness/>. 


\section{A. Reforming The Content of The Rules}

The content of Alberta's venue rules can be assessed with regard to best practices identified in the literature. When venue rules provide too much flexibility to the plaintiff, the plaintiff may exercise its discretion oppressively. ${ }^{199}$ The plaintiff may use the venue rules "to drive an impecunious [defendant] to an early settlement or to not defend an action where the choice of location is not accessible." ${ }^{200}$ Such rules may also trigger a race to initiate litigation in some types of disputes because the first to commence an action can select where the action is heard.$^{201}$ To offset the mischief caused by giving a plaintiff the ability to choose the venue, lawmakers can lower the threshold that a defendant must meet before the action will be transferred. ${ }^{202}$ Transfer applications act as a check on plaintiffs who might be tempted to sue in a venue because it is inconvenient for the defendant.

The current Court of Queen's Bench venue rules, as articulated in the Rules of Court and interpreted through case law, strike a workable balance between the interests of plaintiffs and defendants. Plaintiffs must sue in a location that is proximate to one of the litigants. Defendants can have the matter transferred by showing that a different location would be more convenient. In weighing the relevant convenience of the parties, courts will consider the impact of venue on a litigant's ability to participate in proceedings. An expedited transfer process is available in proceedings for possession of land. The rules in the Provincial Court task the clerk of the court with setting the location of the pre-trial hearings and the trial and use the location of the defendant or the cause of action as the determinative connecting factors.

There is room for improving the current venue rules. The balance of this section outlines four potential reforms.

\section{Redraft the Provincial Court AND QueEN's Bench VENUE RULES TO REMOVE THE LOCATION OF THE CAuse of ACTION AS A CONNECTING FACTOR}

Both the Court of Queen's Bench and the Provincial Court venue rules use the location of the cause of action as a connecting factor. At the Court of Queen's Bench, a plaintiff with multiple locations must start proceedings in the judicial centre that is proximate to either the defendant or the plaintiff"s location that is nearest to where "the matters in issue in the action arose or were transacted." ${ }^{203}$ In Provincial Court, the clerk must set pre-trial hearings and the trial to be heard either where the debtor is located or where the cause of action arose. ${ }^{204}$

See Edson R Sunderland, "The Provisions Relating to Trial Practice in the New Illinois Civil Practice Act" (1933) 1:2 U Chicago L Rev 188 at 192. Too much choice with respect to where to start a claim can also create administrative difficulties for courts, as Ontario experienced when it amended its civil procedure rules to allow a plaintiff to commence a claim in any venue in the province. The result was that many claims with no connection to Toronto were filed in Toronto, creating significant backlogs: see Ontario Civil Justice Review, supra note 33, ch 5.3.

Twohig \& Pawson, supra note 49 at 155.

Ibid at 145 .

Ibid at $158-59$

Rules of Court (2010), supra note 30, r 3.3(2).

Provincial Court Civil Procedure Regulation, supra note 40, s 16(1). 
Using the location of the parties rather than the location of the cause of action as the key connecting factor in venue rules is preferable for two reasons. First, it is easier to identify where a party resides or carries on business than it is to identify where "the matters in issue in the action arose or were transacted." 205 For example, imagine that a plaintiff alleges that a contract was breached by conduct that occurred in Edmonton. The contract was purportedly entered into at an office in Grande Prairie, and the defendant raises as a defence that the contract was never properly executed. ${ }^{206} \mathrm{Did}$ the issue arise in the location where the contract was purportedly entered into or the location where it was allegedly breached? Rules that incorporate the place in which an issue arose as a consideration can foster needless litigation over the venue because parties are able to fight over how the action should be characterized and where the key elements of the claim occurred. ${ }^{207}$ Such rules may result in unnecessary expenses and delay because they require parties to prove essential facts going to the merit of the case on an initial venue transfer motion. ${ }^{208}$ Savvy plaintiffs may avoid venue-based challenges by strategically framing their pleadings. ${ }^{209}$ Venue rules should "encourage the litigation of the merits of cases and not the litigation of procedural issues," that considers where an issue "arose or [was] transacted"211 threatens to do the latter.

Second, a party's proximity to a judicial centre is a better proxy for the convenience of the litigants than is proximity to where the action arose. We have come a long way from fourteenth century England, when it was important to litigate in the venue where a matter arose so that the sheriff could recruit sufficiently knowledgeable jurors. In twenty-first century Alberta, the context of litigation is that many litigants are self-represented, and most matters are resolved before trial. Imagine a Court of Queen's Bench action involving a defendant, who resides in the southeast corner of Alberta (near Lethbridge), and plaintiff, who carries on business in southern Alberta (near Lethbridge) and Central Alberta (near Edmonton). The defendant committed a tortious act in the northeast corner of the province (near Fort McMurray). Under the current rule, the plaintiff could choose to sue in Lethbridge, near the defendant, or in Edmonton, its closest place of business to where the tort occurred. If there are witnesses coming from Fort McMurray, it may be more convenient to hold a trial in Edmonton because the witnesses are then not required to travel as far. But most matters never make it to trial, and such witnesses will provide evidence for pre-trial motions by way of written affidavit. Moreover, such witnesses will not be present in every case. If the defendant is self-represented and of limited means, travelling from Lethbridge to Edmonton

Rules of Court (2010), supra note 30, r 3.3(2).

This example is derived from Street, supra note 49 at 91.

See Twohig \& Pawson, supra note 49 at 140 ; Stevens, supra note 112 at 331 . Alberta's limitations legislation has moved away from prescribing different limitation periods for different types of actions for this very reason: see Institute of Law Research and Reform, Limitations, Report for Discussion No. 4 (Edmonton: Alberta Law Reform Institute, 1986) at 5, online, <https://www.alri.ualberta.ca/docs/rfd 004.pdf >. Compare Limitation of Actions Act, RSA 1980, c L-15, s 4 with Limitations Act, RSA 2000, c L-12, s 3 .

Clarence Guittard \& John Tyler, "Revision of the Texas Venue Statute: A Reform Long Overdue" (1980) 32 Baylor L Rev 563 at 566.

Twohig \& Pawson, supra note 49 at 145 . Different venue rules may invite different forms of gamesmanship. For example, in response to a venue rule that requires a matter to be started or heard at the judicial centre closest to where the defendant resides may encourage plaintiffs to improperly join actions against multiple defendants, so as to have the matter heard near to a more conveniently located defendant: see Sunderland, supra note 199 at 193; Stevens, supra note 112 at 329; Guittard \& Tyler, ibid at 580 .

Twohig \& Pawson, ibid at 130.

Rules of Court (2010), supra note 30, r 3.3(2). 
land. Evictions are actions by the landlord for vacant possession of the rented premises and qualify as a claim for possession of land, yet can be commenced by originating notice. Writ proceedings may be based on an underlying judgment that initially made no claim in relation to the judgment debtor's land. The rule should be revised to apply any time that possession or sale of land is claimed in proceedings that are not being carried out in the judicial centre closest to the land. To discourage litigants from frivolous applications to change the venue, the form for doing so could clearly state that a litigant may face adverse cost consequences if a venue change application is successfully challenged. ${ }^{213}$

The amended rules should also clarify when a defendant loses the ability to use the expedited venue transfer process. The revised rule should avoid using the close of pleadings as a deadline because this term may be unfamiliar to self-represented litigants and has no applicability to many mortgage proceedings. One approach would be to give a defendant a period of time in which to make use of the expedited process. The time could run from when the defendant first receives notice of litigation (for example, is served with a statement of claim or an originating notice) or enforcement (for example, is served with notice of intention to sell a home).

The revised rule should also specify that once the defendant has served the expedited notice form on the plaintiff, any applications are stayed until either the ten-day objection period elapses or an objection is filed. This provision would prevent a defendant from being required to appear in an inconvenient venue pending the potential transfer of the matter. Admittedly, in residential tenancy proceedings where timelines are short, wily tenants could take advantage of this rule to temporarily stay eviction proceedings. As a result, the tenants may extend how long they can remain in the rented premises without paying rent, but only if the landlords start eviction proceedings at a judicial centre that is not proximate to the rented premises.

The proposed change would only extend the expedited process to claims relating to land and not other types of actions. Venue rules regarding real property actions have traditionally differed from the venue rules governing other types of lawsuits. However, many of the traditional justifications for these different rules have lost force over time. In the past, pleadings for remedies regarding land were considered incomplete unless they properly identified the land in question - and the venue flowed from the facts in the pleadings. Under current practice in Alberta, a litigant commences proceedings by filing documents in a judicial centre and this chosen judicial centre may be located at a great distance from the places described in the pleadings. In the past, holding legal proceedings proximate to a disputed property was justified on the basis that it enabled the Court to collect information about the property by visiting it and taking a view. Courts still have the ability to take a view, ${ }^{214}$ but this power is seldom exercised and, even where it might be, courts can now treat this possibility as one consideration when balancing the convenience of parties. ${ }^{215}$ In the past,

\footnotetext{
213 An additional disincentive for defendants to bring venue change applications in mortgage default proceedings is that mortgages generally allow the lender to recover any costs it incurs in default proceedings from the value of the secured property. Unfortunately, defendants are not always aware of this provision.

214 Rules of Court (2010), supra note 30, r 6.26

215 See notes 133-34 and accompanying text.
} 
it was argued that a court order would be easier to enforce if granted in the venue where the land was situated. This rationale continues to have resonance when a party is deciding in which jurisdiction to sue. Before a court order granted outside of Alberta can be enforced in Alberta, the Alberta court must recognize the order. However, this justification carries no weight when deciding between different venues within Alberta. An order requiring the transfer of title or the vacating of a home will be carried out by the Land Titles Office or by a bailiff regardless of where in Alberta the order was granted.

Many of the traditional reasons for having special venue rules for litigation over land no longer carry weight, but there are still sound reasons to treat such litigation differently. First, it is a straightforward exercise for litigants, clerks, and judges to identify the location of a disputed residence. Arguments over which judicial centre is closest can be easily resolved. Second, and more importantly, housing is a basic necessity, and individuals should not be deprived of it without being afforded a meaningful opportunity to defend the proceedings. The reason advanced in this article for holding legal proceedings close to the land under dispute is because it promotes access to justice and reduces the likelihood of individuals losing their homes when they have a meritorious defence to an action. Giving a person the opportunity to object to the venue of litigation prior to losing their home is a relatively minor procedural safeguard and will cause little extra inconvenience for plaintiffs who are already complying with the venue rules. If a plaintiff has a good reason to resist the venue change application - imagine a low-income plaintiff seeking to enforce a judgment against land in a remote part of the province — the expedited process provides the litigants with a simple way of getting the question of venue before the Court, and the Court will consider the plaintiff's financial situation under the current test for transferring venue.

Some mortgage default and writ enforcement proceedings may be carried out against properties that are not the defendant's principal residences (such as vacation homes and rental properties owned by the defendant, i.e., where the defendant is the landlord). Access to justice concerns are less salient in these contexts. One option would be to limit the expedited process to situations where the plaintiff is bringing proceedings against a defendant's principal residence. On the other hand, when legal proceedings are taken against a defendant landlord's rental properties, the tenants may wish to appear in court and speak to the nature of the relief being granted. The tenants may be better able to appear when the matter is heard at a courthouse proximate to the disputed real property. The rights and remedies of tenants in mortgage default and writ enforcement proceedings raise difficult policy questions and merit further consideration. ${ }^{216}$ For the purposes of this article, a tenant's potential involvement in mortgage default proceedings is a good reason not to limit the applicability of the expedited process to proceedings against an owner's principal residence.

Other types of legal proceedings can infringe on an individual's basic needs or fundamental rights. This feature is not exclusive to the proceedings discussed in this article. There are meritorious reasons to consider further expanding the scope of the expedited venue transfer process to ensure that litigants in these other actions are not denied a meaningful 
opportunity to participate in litigation. ${ }^{217}$ Such changes raise different considerations, and their analysis is left for another day.

\section{EXPAND THE AVAILABILITY OF REMOTE APPEARANCES ON PRE-TRIAL APPLICATIONS}

The default rule in the Court of Queen's Bench and Provincial Court should be that parties can appear on pre-trial applications by telephone or video conference, subject only to the Court ordering otherwise. The Court could make such an order on its own motion, when it feels a personal appearance is necessary, or it could make such an order in response to an application by one of the litigants. Remote appearances would reduce out-of-pocket and temporal costs for all litigants and ensure that individuals living in remote areas, those with restricted mobility, and those with limited access to transportation are not precluded from participating in legal proceedings. ${ }^{218}$ Making remote appearances readily available would have other ancillary benefits. For instance, it would facilitate appearances by those individuals who make up Alberta's large, transient workforce — including the many Canadians and temporary foreign workers who travel to Alberta to work in the oil patch. ${ }^{219}$ These litigants may be living in a different province or country by the time a matter makes it to court.

Even more drastic technological innovations are imaginable. For example, an entirely online dispute resolution platform has been developed for landlord-tenant disputes in the Netherlands. ${ }^{220}$ In British Columbia, the new Civil Resolution Tribunal provides an online dispute resolution platform to litigants with small claims and condominium property matters. ${ }^{221}$ Any technological innovations must be implemented carefully to avoid reinforcing the marginalization of disempowered groups, but they hold promise too. ${ }^{222}$ Making remote appearances available as the default is only a good starting point, not the final word on the possible uses of technology.

\section{B. Reforming Related Practices}

The bigger problem with Alberta's venue rules relates not to their content but to the process necessary to enforce them. Even where the substantive law favours a venue change, self-represented litigants may struggle to avail themselves of their rights. Academics have recognized that procedural rules can pose a particularly intractable hurdle for self-represented

See e.g. Rosen, supra note 24 , who argues in favour of a special venue rule for consumer transactions. See Semple, supra note 15 at 670.

For example, Fort McMurray, which is located near to Alberta's oil sands, had a "shadow" population of mobile workers numbering 51,000 in 2014 and 43,000 in 2015. Many of these individuals reside in Alberta temporarily while working but return home to other parts of Canada on their days off: Chris Turner, The Patch: The People, Pipelines, and Politics of the Oil Sands (Toronto: Simon \& Schuster Canada, 2017) at 135 . The federal government's temporary foreign worker program is designed to enable employers to bring in individuals from other countries when they are unable to find sufficient Canadian employees: Immigration, Refugees and Citizenship Canada, "Fact Sheet-Temporary Foreign Worker Program," (Ottawa: IRCC, 2015), online: <https://www.canada.ca/en/immigration-refugeescitizenship/corporate/publications-manuals/fact-sheet-temporary-foreign-worker-program.html> . Maurits Barendrecht et al, "ODR and the Courts: The Promise of 100\% Access to Justice?" (HiiL, 2016) at 39, online: Issuu <https://issuu.com/hiilrechtwijzertechnology/docs/hiil_online_dispute_resolution_ tren $\mathrm{d} 5 \mathrm{f} 3 \mathrm{bbbcedea3d}>$.

Civil Resolution Tribunal Act, SBC 2012; Salter, supra note 15.

Hughes, supra note 16. 
litigants. ${ }^{223}$ One goal of revising the Rules of Court in 2010 was to "advance justice system objectives for civil procedure such as fairness, accessibility, timeliness and cost effectiveness." ${ }^{224}$ The Steering Committee contemplated how to achieve this goal with respect to self-represented litigants and determined that self-represented litigants would benefit from the Committee's efforts to simplify the language and procedures contained in the Rules. ${ }^{225}$ This work remains incomplete, and the procedures adopted in the Court of Queen's Bench continue to create obstacles for self-represented litigants.

In the Court of Queen's Bench, litigants requesting a change of venue must prepare and file a notice of application and an affidavit in support, and then appear at the courthouse to argue in favour of the application. ${ }^{226}$ If the litigants wish to appear electronically on the venue change applications and, they must ask to appear electronically both in their notice of application and in an additional written request to the Court. By requiring these steps, the Rules of Court may prevent many self-represented litigants from making venue change applications.

A master or justice of the Court of Queen's Bench will hear a venue transfer or electronic appearance application in motions court. Every self-represented litigant who appears in motions court brings a different set of skills and challenges to the courtroom, yet a thread that ties many of them together is that they are unfamiliar with the procedural rules governing how matters are decided. ${ }^{227}$ Many self-represented litigants do not know that their evidence needs to be provided in a written affidavit. Instead, they come to court prepared to provide oral testimony about the underlying dispute. An even smaller number of litigants seem to be aware that if they want a specific remedy from the Court, they must prepare and file a notice of application and then serve it on any adverse parties ahead of the court date. These are the obstacles faced by those litigants who make it to the courthouse. Many litigants do not appear at all - mortgage default and eviction applications regularly proceed uncontested. ${ }^{228}$ Moreover, it is likely that many tenants move out of rented premises earlier in the eviction process, rendering a court application unnecessary. The sale of land pursuant to writ proceedings only goes to court if the homeowner (or another interested party) objects to the sale process.

See Roderick A Macdonald, "Access to Justice in Canada Today: Scope, Scale and Ambitions" in Julia Bass, WA Bogart \& Frederick H Zemans, eds, Access to Justice for a New Century: The Way Forward (Toronto: Law Society of Upper Canada, 2005) at 28; Marguerite Trussler, "A Judicial View on SelfRepresented Litigants" (2001) 19 Can Fam LQ 547 at n 55.

Alberta Law Reform Institute, "Final Report," supra note 96 at 4. See also Peter JM Lown, "Rules of Court Project" (2005) 42:3 Alta L Rev 907 at 907-908.

Alberta Law Reform Institute, "Self-Represented Litigants," supra note 14 at paras 119-25. The Committee rejected building any manner of special treatment for self-represented litigants into the rules: ibid at paras 6, 118 .

Rules of Court (2010), supra note 30, r 6.3(3). The Court does retain the ability to transfer a matter on its own motion: see supra note 128.

The observations in this paragraph are based on the author's experience providing legal assistance to the self-represented litigants appearing in morning Masters and Justice Chambers through Pro Bono Law Alberta's Court of Queen's Bench Amicus Program in Edmonton between 2015 and 2018. On the lack of procedural knowledge amongst self-represented litigants appearing in Chambers, see also Trussler, supra note 223. Further "law in action" research testing the accuracy of these observations would be beneficial.

Lim, supra note 23 at para 9 ("a minority of foreclosure defendants appear in court"). 
The procedural hurdles created by Alberta's venue rules are not unique. In a 2007 report on civil justice in Ontario, Justice Coulter Osborne heard similar concerns from practitioners located in remote parts of his province about the processes applicable to venue rules. ${ }^{229}$ The substance of the venue rules was unobjectionable, but the process for transferring an action from one venue to another was costly. Justice Osborne recommended adopting a streamlined process, where a party could have the venue transferred simply by filing a short motion form and, if necessary, an affidavit in support. In cases requiring submissions, he recommended that either the submissions be made in writing or by telephone (so as to accommodate remote appearances) or that the rules be amended so that an application to change the venue could be brought in any location in Ontario. Finally, he recommended that applicants be granted full indemnity costs in cases where it was clear that the venue should be changed because of the overwhelming connection between the claim and the venue to which it was being moved. $^{230}$

The previous section recommended similar reforms - expanding the scope of the expedited venue transfer rule and making remote applications available by default. This section outlines other changes that might empower self-represented litigants to navigate the process of applying for a transfer. ${ }^{231}$

\section{USE COURT Forms TO EDUCATE LitigANTS About the Venue Change Process}

Litigants may not be aware that they can request a change of venue. ${ }^{232}$ One method of bringing this option to their attention would be to require that plaintiffs and judgment creditors include information about the venue change application process in the documents served on defendants and judgment debtors (for example, a commencing document or a notice of intention to sell). ${ }^{233}$ Such a process is already used in the Provincial Court to advise defendants about their right to file a defence and in writ enforcement proceedings to provide judgment debtors with information about their ability to claim some property as exempt. ${ }^{234}$

Even if litigants are aware they can request a venue change, they may not know how to; well-designed court forms can guide them through this process. The Alberta Courts provide a Family Law Kit on how to transfer a court file, which includes a template notice of application and affidavit. ${ }^{235}$ This kit could be modified for use in actions in civil court and to include information on the expedited process. The Rules of Court stipulate the form

Honourable Coulter A Osborne, "Findings \& Recommendations" (Toronto: Queen's Printer for Ontario, 2007), online: <https:/www.attorneygeneral.jus.gov.on.ca/english/about/pubs/cjrp/>.

See also Rosen, supra note 24 at 546, who recommended that defendants be allowed to apply for a change of venue in writing.

See also Deborah J Cantrell, “Justice for Interests of the Poor: The Problem of Navigating the System without Counsel” (2002) 70 Fordham L Rev 1573.

Lim, supra note 23 at para 10.

Rosen recommends the inclusion of such a notice in her model legislative provision that would govern venue in litigation arising from consumer transactions: supra note 24 at 546-47.

For example, when a bailiff seizes personal property, the bailiff must serve the debtor with seizure documents, which includes a form entitled "Information for Debtors" listing the possible exemptions a debtor may claim: see CEA, supra note 37, s 45; Civil Enforcement Regulation, Alta Reg 276/1995, s 2, Schedule 4.

Alberta, Resolution Services, Court of Queen's Bench Application to Transfer File (Resolution Services, 2016), online: $<$ https://www.alberta.ca/assets/documents/rcas-court-of-queen-39-s-bench-application-totransfer-file.pdf $>$. 
litigants are to use when invoking the expedited venue transfer rule. ${ }^{236}$ If the scope of the expedited venue transfer rule is expanded as recommended above, this form will need to be revised.

All of these documents should be reviewed to ensure they are accessible to selfrepresented litigants. The complexity of court forms creates significant obstacles to litigants. ${ }^{237}$ Additionally, low literacy levels, lack of proficiency in English, and unfamiliarity with technical legal terms can hamper self-represented litigants from making use of court forms and other information resources. ${ }^{238}$ To avoid these pitfalls, the forms should employ an appropriate reading level and make use of straightforward, simple language. ${ }^{239}$ In addition to being provided with information, self-represented litigants may also require encouragement about their ability to navigate the litigation process. Self-help documents drafted with an appropriate tenor may help empower self-represented litigants. ${ }^{240}$

\section{EDUCATE INTERMEDIARIES ABOUT THE USE OF THE COURT FORM}

When trying to resolve issues about venue, self-represented litigants may seek direction from courthouse personnel, including the clerks at the front desk of the courthouse registries and individuals at other court programs such as Dispute Resolution Services and Pro Bono Law Alberta's Amicus Program and Civil Claims Duty Counsel. ${ }^{241}$ An additional guide, explaining how to properly complete the venue change forms, may be of assistance - either to the self-represented litigant or to these intermediaries. ${ }^{242}$ The intermediaries will be better able to serve self-represented litigants if they receive training on the forms and guides. ${ }^{243}$

Procedural reforms, even relatively minor ones like the ones suggested in this article, can have a real impact on how individuals experience the justice system. They reduce the risk that defendants with meritorious defences will lose their homes because they have been sued in inaccessible locations. They can also shift attitudes amongst those individuals who people

The Rules of Court already stipulate the form litigants are to use when invoking the expedited venue transfer rule: Rules of Court (2010), supra note 30, Form 6.

The Right Hon Brian Dickson et al, Report of the Canadian Bar Association Task Force on Systems of Civil Justice (Ottawa: Canadian Bar Association, 1996) at 16, 55.

Barbara Billingsley, Diana Lowe \& Mary Stratton, Civil Justice System and the Public: Learning from Experiences to Find Practices That Work (2006) at 33, online: Canadian Forum on Civil Justice $<$ cfcjfcjc.org/sites/default/files/docs/2006/cjsp-learning-en.pdf>; Rachel Birnbaum, Nicholas Bala \& Lorne Bertrand, "The Rise of Self-Representation in Canada's Family Courts: The Complex Picture Revealed in Surveys of Judges, Lawyers and Litigants" (2012) 91:1 Can Bar Rev 67 at 86; Hughes, supra note 16 at 13 .

Macfarlane, supra note 196 at 114. See also Amy Salyzyn et al, "Literacy Requirements of Court Documents: An Under-Explored Barrier to Access to Justice" (2016) 33:2 Windsor YB Access Just 263; Canadian Judicial Council, Statement of Principles on Self-Represented Litigants and Accused Persons (CJC, 2006) at 6, online: <https://www.cjc-ccm.gc.ca/cmslib/general/news pub other Principles Statement 2006 en.pdf $>$ [Principles].

Cantrell, supra note 231 at 1587.

Lois Gander, Diana Lowe \& Mary Stratton, "The Civil Justice System and the Public: Highlights of the Alberta Pilot" (2005) 42:3 Alta L Rev 803 at 809; Macfarlane, supra note 196 at 116-17. Hughes argues that, for some people with limited "literacy skills, difficulty with language or cognitive challenge," this in-person assistance is necessary if they are to make use of self-help resources: supra note 16 at 19. Gander, Lowe \& Stratton, ibid at 811; Dickson et al, supra note 237 at 55.

Gander, Lowe, \& Stratton, ibid at 809; Macfarlane, supra note 196 at 117-18; Principles, supra note 239 at $8-11$. 
the justice system - court staff, legal professionals, and judges. ${ }^{244}$ The lawyers who enforce mortgages and residential tenancies and those who collect debts tend to have high-volume practices, and the reality of the impact of litigation on any one defendant can be obscured in the onslaught of paperwork. Court staff, pro bono volunteers, and judicial officers are likewise overwhelmed with a huge number of self-represented litigants facing real peril. There is an understandable temptation to harden oneself against these litigants and to minimize the seriousness of the consequences they face. Enabling self-represented litigants to enforce the venue rules reminds the other actors in the justice system that defendants are more than mere obstacles to the speedy resolution of a file. Important rights are being adjudicated, and the defendants' involvement in the process should be facilitated, not discouraged.

Although important, the impact that any procedural reform will have on individuals facing housing insecurity is limited. Procedural reform does not provide those litigants facing the loss of a home as a result of unpaid debts, unpaid rent, or unpaid mortgages with any additional substantive defences. Nor do such reforms address underlying issues of distributive justice, including low wages, lack of affordable housing, restricted economic opportunities, and financial precarity. ${ }^{245}$ The reforms suggested in this article are, ultimately, small changes. They are straightforward to implement, but they are best viewed as an inauspicious contribution to the project of enhancing housing security by promoting access to justice. At the same time, this article offers some insights that may be valuable to these bigger projects.

This article concludes by identifying four such insights.

First, this article illustrates that lawyers, judges, and legislators must be alive to many different types of barriers if they wish to ensure equitable access to justice. With respect to venue rules, it is the intersection of geographic and financial barriers that makes some locations inaccessible to some litigants.

Second, this article underlines that substantive changes to laws, such as creating additional defences for litigants facing the loss of a house, are of little use if the processes for invoking such laws are impenetrably complex.

Third, this article points towards the need for "law in action" research examining how individuals in Alberta's justice system actually experience the civil procedure rules. Such research will help identify what rules and related practices are most in need of reform.

Finally, this article suggests that it may be time to re-evaluate the "neutral" approach adopted when the Rules of Court were revised in 2010. At that time, the Steering Committee rejected building any manner of special treatment for self-represented litigants into the use of alternative dispute resolution mechanisms in "Will Changing the Process Change the Outcome? The Relationship between Procedural and Systemic Change" (2005) 65:4 La L Rev 1487 at 1497-98. On the shortcomings of most access to justice initiatives for reform, see Macdonald, supra note 13 at at 292 . 
rules. ${ }^{246}$ The Supreme Court of Canada has since indicated that self-represented litigants may require special treatment if access to justice is to be meaningful. In Pintea $v$. Johns, the Supreme Court of Canada endorsed the Canadian Judicial Council's Statement of Principles on Self-represented Litigants and Accused Persons. ${ }^{247}$ The Principles acknowledge that selfrepresented litigants face particular challenges negotiating the legal system. The Principles call on judges to "exercise diligence in ensuring that the law is applied in an even-handed way to all, regardless of representation" 248 — and this may require treating self-represented litigants differently from those with representation. A question warranting further consideration is whether judges are able to apply the existing "neutral" civil procedure rules in a manner that ensures self-represented litigants are able to participate meaningfully in litigation or whether the rules should be revised to take account of the particular challenges facing self-represented litigants. Coming up with a well-considered answer to this question could enhance access to justice generally but is especially relevant to the three types of proceedings considered in this article, where defendants are frequently self-represented. online: Representing Yourself Canada $<$ https://representingyourselfcanada.com/wp-content/uploads/ 2017/11/Pintea-Summary.pdf $>$. 